\title{
Masaharu Tanaka, Preface: Introduction to Liberal Economic Thought
}

\section{Translated by Robert Chapeskie and Hideo Tanaka*}

\section{Introduction by Hideo Tanaka}

The late professor Masaharu Tanaka (1925-2000), president of JSHET from 1985-86, edited The Comparative Study of Liberal Economic Thought, a book published in 1997 by The University of Nagoya Press. He wrote a long preface to it, and this English article is a translation of that essay.

During his two years as a junior researcher under Michio Morishima at Kyoto University, Tanaka began his studies with Max Weber's Wissenschaftslehre before moving on to the study of 18th century French social thought and later Marx, Lenin and Prehanov. His Doctoral Dissertation was on the History of Russian Economic Thought, including the Narodniks, Marxists, and other movements. He became a professor of economic theory after its publication in 1967. With the decline of socialism, the focus of the economics academy in Japan gradually shifted from Marxist political economy to Anglo-American economics.

Tanaka and his study group (his former students and other scholars) started the "society for the study of methodology of social sciences" in 1980, and continued to hold monthly meetings until his death. As mentor of this society, Tanaka read various books concerning liberalism and other topics. He found Hayek's work important, and translated several of his essays in collaboration with his student Hideo Tanaka, publishing them as Market, Knowledge, and Liberty in 1986, a book that became a forerunner of the "Hayek boom" in Japan.

The Comparative Study of Liberal Economic Thought was widely read, and

\footnotetext{
* Assisted by Junichi Himeno, Shinji Nohara, Yuichiro Kawana, and Takato Kasai for identifying original sources.

The History of Economic Thought, Vol. 58, No. 1, 2016. (C) The Japanese Society for the History of Economic Thought.
} 
Tanaka's introduction is considered an excellent essay offering a wide overview of economic liberalism from the 18th to the 20th centuries.

The book is comprised of 12 articles as follows:

Preface Introduction to Liberal Economic Thought

Chap. 1 Fragile Clock: Early Newtonianism

Masaharu Tanaka and the Formation of Political Economy

Chap. 2 Liberalism in Physiocracy

Shinichi Nagao

Chap. 3 Precedent Paradigms and the Political Economy

Kuniyasu Morioka of Smith

Chap. 4 The Market Economy System and Liberty: By way of Marx's Theory

Chap. 5 Economic Liberalism in Austria: In the Case of Max Menger

Chap. 6 Progress and Liberty in Marshallian Economics

Chap. 7 The Political Philosophy of J. M. Keynes:

Hideo Tanaka Burke and Keynes

Chap. 8 Pragmatism and American Liberalism:

Takashi Yamamoto 'Intelligence' and 'Liberty'

Chap. 9 The Exile Russian Liberal Economics:

Shuichi Kojima Soviet Socialism in Boris Brutzkus

Chap. 10 Liberalism and its Foundation: Atsushige Matsushima Mainly in the Cases of Walras and Hayek

Market Economy Terminology Masaharu Tanaka Afterword Masaharu Tanaka

\section{I}

Liberal economic thought (economic liberalism) is one form of liberalism. Liberty is the foundation of liberalism. We must therefore begin by examining liberty.

From ancient times, there have been many definitions of liberty. From debates over free will to discourse on liberty in a social sense, the definition of liberty has differed depending on that in relation to which it is being considered. Liberty defined in relation to necessity is ability or insight, ${ }^{1}$ while liberty in a social sense is, more than anything else, liberty from bondage. Liberty that is connected to economic liberty is liberty in a social sense. Limitations of personal liberty, or the natural defects or limitations of capability shared by all humankind, however constraining they may feel, are irrelevant to liberty in the social sense. Liberty or a state of liberty in a social sense is a state of affairs in which 
individuals are subjected to as little bondage/coercion at the hands of other groups or individuals as possible. The larger the domain of what a person can do, the more leeway individuals are given to behave as they like, the greater the degree of liberty of the society in question. ${ }^{2}$

It is untenable, however, for individual liberty to be made infinitely expansive. Unlimited liberty for all persons, while it might be an anarchist's utopia, would in practice be a Hobbesian state of nature in which liberty is extinguished. In order for a person's liberty to be compatible with the liberty of others, a clear boundary must be drawn between the domain in which an individual can act freely and the domain in which they cannot, namely, the domain in which coercion must be accepted. Where should this border be drawn? John Stuart Mill considered the domain of what was directly related to the person in question to be "sacred ground" on which the intrusion of others was not to be tolerated. Most acts are indeed related to other people, but acts in which the manner of influence present in this relationship does not exceed indirect action and become direct belong to individual liberty ("sacred ground"). Matters that might directly harm others must be governed by social authority. Freedom of speech and freedom of publication belong to individual liberty, because while such activities can of course influence others, they do not compel or coerce them, and as long as the people in question possess the faculties of an adult they naturally have the ability to discard or disregard what they read or are told. ${ }^{3}$ This example is easy to understand, but in general the border between these domains is not quite so clear. To acquire a certain position is to exclude others

1 John Locke, "Liberty ... is the power a man has to do or forbear doing any particular action," An Essay concerning Human Understanding, Bk. II, Chap. 21, Sec. 15 (Penguin Classics, 1997, p. 226). David Hume's definition is very similar. An Inquiry Concerning the Principles of the Morals, chap. 8, Sec. 1, para. 73. These are definitions of liberty in contrast to necessity. For a definition that sees liberty and necessity as congruent, see Hegel, "The truth of necessity is liberty," System der Philosophie, Erster Teil. Die Logik, Sect. 158. Engels, "According to Hegel, liberty is insight into necessity," Anti-Dühring, Bk I, chap. 11. See also the various definitions presented in M. Cranston, Liberty, 1967, Pt. I, sect. 3.

2 See, Hayek, Works, Vol. 5, 1960, pp. 11-13.

3 Mill counts the following as belonging to the proprietary domain of human liberty directly related to oneself: (1) Liberty of conscience, liberty of thought and feeling, liberty of expression and publication of opinions; (2) liberty of tastes and pursuits, liberty to plan one's life, liberty of acts that do not harm one's compatriots; (3) Liberty of organisation in a group as long as it does not harm others. John Stuart Mill, On Liberty, 1859, in ditto, Essays on politics and society, ed. by J. M. Bobson, (University of Toronto Press, 1977), pp. 255-56. Regarding the "sacred ground" of the individual on which the intrusion of others is not to be permitted, see John Stuart Mill, Principles of political economy with some of their applications to social philosophy (London: J. W. Parker, 1848), pp. 506-07. 
from it. Such is the nature of "competition."

Regarding individual liberty under the law, it is stipulated that "liberty is the power that belongs to man to do whatever is not injurious to the rights of others, ${ }^{4}$ and if the content of human rights is clearly stated, the domain of individual liberty can be formally defined. To be precise, however, drawing the borders between individual human beings alone is not sufficient; it is also necessary to stipulate the property and rights belonging to states/governing bodies (the right of taxation, for example). Liberty can be said to be the domain of what the law does not prohibit, or the domain of that upon which the law is silent. A society with a large degree of liberty is a society that occupies a position between an anarchical society and a controlled society, as close as possible to the former while still being clearly distinguished from it.

But it is not only the law that restricts individual liberty. Human beings live within a thick layer of traditions and customs. If you act against these traditions or customs you will not receive legal punishment. But there are cases in which you will suffer retaliation in the form of ostracism or social exclusion, and this can be severe enough to make life very difficult. ${ }^{5}$

What I have discussed so far has been individual liberty in a social sense. As this is liberty from coercion or constraint, it is also referred to as "negative liberty." This "negative liberty," however, is essential or fundamental liberty.

One kind of positive liberty is what can be referred to as "internal liberty." It is sometimes claimed that true liberty is genuine self-realisation, avoiding irrational temptation and acting in accordance with moral maxims, awareness of oneself as an instrument of God, acquiring a feeling of oneness with God or the universe through mediation or religious practice, or devoting oneself to social reform. It is indeed the case that a feeling of satisfaction in life cannot be obtained through only the negative liberty of not being forced or coerced. Feelings of positive liberty presumably arise out of self-discipline or an orderly way of life. But while in most cases positive liberty is a good thing, when it becomes action, affects other people, and falls outside of the framework of liberty established under the law, it becomes "revolution" when it succeeds and "crime"

4 The first half of the 6th article of "Declaration of the man and the citizen" in 1793.

5 Mill's On Liberty was an assertion of the liberty of individuality in the face of the oppression of Victorian middle-class customs and moral conventions (the pressure of public opinion). Mill lamented the suffocation of individuality by tradition and customs, while Friedrich Hayek said that tradition and customs are in fact the soil in which individuality is nurtured, although both thought "human development in its richest diversity" (Humboldt) was of the greatest importance. The quote from Humboldt is included on the front page of Mill's On Liberty and is also used in the conclusion of Hayek's The Constitution of Liberty. 
when it fails.

In political liberty there is both positive liberty and negative liberty. ${ }^{6} \mathrm{Nega}-$ tive liberty is not being constrained by political authority, and this is the political aspect of the liberty discussed above (negative liberty). The less one is coerced/constrained by a specific ideology or by legal or governmental orders, the greater this liberty. Positive political liberty means limiting the authority that exists and participating in authority oneself. These two types of liberty are different. Negative liberty can exist even when there is no participation in politics, and there are cases in which negative liberty is severely constrained even though there is positive political liberty. According to Isaiah Berlin, negative liberty is a question of how many doors are open to you, while positive liberty is a question of who controls these doors.

When the term "liberalism" is used on its own, it is in fact often referring to political liberalism. ${ }^{7}$ British liberalism featured a process in which the middle class gradually limited the privileges of the authority of the crown and aristocracy while increasing the extent of their own participation in power, and this eventually led to the political participation of women and the working class. In France the ancien régime was overthrown suddenly, the citizenry (or people who pretended to be its representatives) took the reins of power, backlashes

6 See I. Berlin, "Two Concepts of Liberty" (1965) in I. Berlin, Liberty, ed. by H. Hardy (Oxford U. P., 2002), pp. 168ff. Four Essays on Liberty (London, Oxford, and New York: Oxford U. P., 1969), pp. 121ff. and Isaiah Berlin and Ramin Jahanbegloo, Conversation with Isaiah Berlin (Charles Scribner's Sons, 1991) pp. 40-43.

7 Until the end of the 18th century, the word "libéral" or "liberal" existed only as an adjective (the nouns "liberty" and "freedom" were of course already in use). It was used to mean "generous" or "humane," and had not yet been applied to politics. This term entered the domain of politics with Napoleon's declaration of political control (1799), and signified the idea of tolerance. In 1812 the "Liberales party" appeared in Spain, the main aim of which was the establishment of a constitutional system of government. According to the $O E D$, in 1816 the political term "British liberals" appeared as a pejorative description of radical elements within the Whig party used by the Tories, and in 1819 the term "liberalism/libéralisme" appeared in both Britain and France. Cf. G. de Bertier de Sauvigny, "Liberalism, Nationalism, and Socialism: the Birth of three Words," Review of Politics, Vol. 32, 1970, p. 147f., esp. pp. 150-53. The standard Japanese translation of the term became jiy $\bar{u}$ [自由] rather than jishu [自主] or jizai [自在] after Masanao Nakamura's translation of J. S. Mill's On Liberty, entitled Jiyū no ri [自由之理] (1872). Prior to that the term jiyū had mainly signified "selfishness" in Japanese, but in Zen Buddhism it was used in the phrase jiyūkaihō [自由解放; emancipation] and there are examples of its being used to mean "liberation from bondage" in Christian writings. See Yoshihiko Amino, Muen · Kugai • Raku (Non-relation, Public Sphere, and Pleasure) (in Japanese) enlarged ed., Heibonsha, 1987, pp. 303-04, Akira Yanabu, Honyakugo Seiritu Jijyo (On the way of Creating Translation Words) (in Japanese), Iwanami Shoten, 1982, pp. 175-91. 
against this change occurred, and the political system was subjected to upheaval. In America, the lands that had been gained without plunder or violence independence from the "mother country" and attained political liberty. Regardless of the various processes by which positive political liberty is realised, in political terms "democracy" is a more suitable name than "liberalism" for the acceptance of popular sovereignty and establishment of a parliamentary or presidential system with regular elections.

In the case of economics, unlike that of politics, positive liberty, namely, the liberty to participate in an economy, cannot be considered separately from negative liberty. This is the case because economic liberty is essentially negative liberty, and positive participation in some kind of economic organisation or activity, too, is included within the liberty of not being under economic coercion/constraint.

Economic liberalism is thought or policy that aims to realise economic liberty to the greatest extent possible. When it comes to "policy," however, it takes a negative or passive tack and does not propose specific programs such as protectionism. ${ }^{8}$ In one sense it is the self-negation of policy. Because of this it is easy to view the economic thought of liberalism as "laissez-faire" in the sense of leaving the current state of affairs as it is without doing anything, but that understanding is incorrect. The economic thought of liberalism arose as a reform movement that aimed to abolish various legal systems, government orders, policy frameworks, and practices that impeded economic liberty and create an order in which free competition (market mechanism) could adequately function. It must be understood that the negative activity of eradicating obstacles was an innovative, positive school of thought. This thought was connected to systemic reform in a broad sense.

What is the nature of the relationship between economic liberty and political liberty? Economic liberty can be expanded even under despotism. Economic control can be strengthened even in a democracy. These are not just logical pos-

8 For this reason, economic liberty has the same character as the social liberty described at the beginning of this chapter and occupies its core. Ludwig von Mises opposed positioning political liberty and economic liberty as parallel to each other, believing that the "market economy" was the foundation of liberalism and if it were destroyed all liberty would be destroyed along with it. Cf. L. von Mises, "Liberalismus" ("II. Wirtschaftlicher Liberalismus," HdSW, Bd. 6, 1959, S. 569ff.) Hayek said the distinguishing between political and economic freedom in traditional British Whig spontaneous-order, evolutionary liberalism, unlike continental rational, constructivist liberalism, was a mistake. See "Liberalism," in New Studies in Philosophy, Politics, Economics and the History of Ideas, Routledge and Kegan Paul, 1978, pp. 132ff. He takes the same position in The Constitution of Liberty (1960). Since society is not completely regulated by economics, however, I have adopted the conventional distinction between political liberalism and social liberalism. 
sibilities, but states of affairs that have actually existed in history. As a result, economic liberty and political liberty are not necessarily bound together. Apart from a few exceptional situations, however, since the 18th century they can be said to have had an affinity for each other. While today a trend toward economic liberty (market economies) and political liberty (democracy) can be seen not just in developed countries but throughout the world, it is a historical fact that predictions about the future have almost always turned out to be false.

What I mean by the word "liberalism" should be clear from what is stipulated above and discussed in Section II of this chapter, but the term itself is actually used in a variety of ways. In Britain it refers to the liberal tradition of opposing the socialist policies/expansion of social welfare of the Labour Party, and politically the Conservative Party has been the party of liberalism. In both Britain and developed countries in general, however, the policies of both left and right-leaning political parties have been moving closer to this school of thought.

In America, the positive view of things like social welfare that continues the tradition of the New Deal is called liberalism. ${ }^{9}$ My definition is closer to the British approach. As may be understood from what follows, however, movement toward the welfare state need not be thought of as simply socialist, and can be understood as a coming together of "new liberalism" and socialism. In America, John Kenneth Galbraith, who went beyond Keynesianism to the brink of socialism (although he was not a socialist), described himself as a "liberal," while Milton Friedman, whose views were completely antithetical to Galbraith's, also referred to himself using this term. Each thought the other was an enemy of liberty.

Within liberalism, too, it can be difficult to distinguish the type of liberalism that is not a rational liberalism but rather one that emphasises mores and customs from conservatism. In practice, there are cases in which liberalism is equivalent to conservatism. In truth, however, liberalism and conservatism are not the same thing. In its essence, the mentality of conservatism is one that opposes change in any direction and seeks to maintain the old way of doing things, and not one that possesses a particular orientation of its own. Liberalism has an orientation toward liberty and a positive appreciation of new things that arise spontaneously. While there may be respect for customs and traditions, here a natural selection and rejection must be operating. ${ }^{10}$

9 See Takeshi Sasaki, Conservatism in Contemporary America (in Japanese), Iwanami Shoten, 1984, particularly Chapter One.

10 See Hayek, "Why I am not a Conservative," in Works, Vol. 7. My explanation, however, differs slightly from Hayek's. 


\section{II}

The foundation of economic liberty is the liberty to dispose of money and goods, differentiating the ownership (rights) of "these goods belongs to person A" and "those goods belong to person B."

The further back you go in human history, the more the individual was immersed in a community as one of its members. While both today and in the past, the family is a community, the degree of independence of individuals within families has differed historically. And in earlier eras the family itself was embedded within a larger community such as a clan or tribe. ${ }^{11}$

These communities were bound together by ties of blood relationships, pseudo-blood relationships, and land, and by a belief in a common ancestry, their members knowing each other on a face-to-face basis and being led by a chieftain or head of the tribe. Morals of solidarity, brotherhood/sisterhood, and cooperation naturally came to the fore, and individualistic behaviours and characteristics tended to be disparaged and eradicated. ${ }^{12}$ The transfer of goods within such communities was in the form of redistribution or gifting/reciprocity. ${ }^{13}$ But since not everything these communities needed could be produced internally, there was a need for exchanges with external entities, although the degree to which such exchanges were necessary varied. The first exchanges were carried out by (the representative of) a community and an external party. ${ }^{14}$ This trade with an external party was conducted on the basis of a completely different principle than the redistribution and gifting/reciprocity within the community, namely, the principle of "exchange" that appeals to "mutual self-interest," in which each party, in order to get what it wants, provides what the other party wants to its own benefit. A "silent trade" can be seen as a straightforward expression of this principle. ${ }^{15}$ While the difference in character between a community's inward-facing morality and outward-facing morality is something emphasised by Max Weber, even if unlimited profiting or plundering is permitted re-

11 By "community" here I have in mind not only so-called "primitive communities," but also land occupied by a community, and, after the start of settled agriculture, communal societies in which a consciousness of family is preserved through things like publicly owned land, gatherings, and rituals.

12 F. A. Hayek, The Fatal Conceit: the Errors of Socialism, 1988, pp. 12-13. Hayek calls this kind of sentiment a primitive instinct. He explains that in contrast the morals of civilised societies (market economies), while they are not based on reason, arise somewhere in between reason and instinct, and constitute morals based on spontaneously emerging traditions/customs. He asserts that socialism is "atavism" that aims to revert to our primitive instincts. 
garding external parties (outsiders), to the extent that peaceful, on-going trade is desired, a certain sort of rules governing "trade" are sure to emerge.

The exchanges that began as interactions with external parties then moved inside communities. In order to engage in trade, each trader had to be the owner of the goods in question. The first private property owned by individuals is thought to have been things they made themselves, such as tools, weapons, and jewellery, but as the scope of private property and trade expanded, communities constricted to a corresponding degree. Of course, in certain forms (public land, gatherings, kinship, and so on) communities stubbornly survive, and conversely in some respects restrict individualistic behaviour.

The spread of private ownership and exchange weaves together a circle of markets and social divisions of labour. When both parties go beyond the borders of the communities in which they know all of the other members on sight, an "expanded order of cooperation" 16 is spontaneously formed between individuals who have never seen each other before. In an exchange between A and B, even if $\mathrm{A}$ and $\mathrm{B}$ know each other, the people involved in the various stages of produc-

13 Putting aside classical antiquity, in early medieval Europe, apart from the commerce of Jews on the fringes of society, money had a magical quality, and while it functioned as a measure of value it was not a method of exchange. Kinya Abe, From the Window of the Middle Ages (in Japanese), Asahi Shinbunsha, 1981 (p. 211).

In Japan, too, prior to around the 14th century "exchanges" other than gifting/reciprocity had to be conducted at "markets" that were cut off from the ordinary world. Yoshihiko Amino, Rereading Japanese History (in Japanese), chap. 2. See also Yoshihiko Amino, Muen $\cdot$ Kugai $\cdot$ Raku (op. cit.), chaps. 11 and 12. The following assertion has also been made regarding Japanese history. "The medieval market was born more from the development of local village economies than from direction by Feudal Lords. . . In the middle ages the elements of arts and commerce that were later absorbed in pre-modern castle towns were still included in the village," Mitsuo Shimizu, The Village in Medieval Japan (in Japanese), 1st ed., 1942. Iwanami Shoten, 1996, pp. 285-300. The distinctive characteristics of the market economy in comparison to pre-market economy redistribution/reciprocity were made clear by Karl Polanyi. See Yoshiro Tamanoi et al. eds. and trans., History of Economic Civilization (in Japanese), Nihon Keizai Shinbunsha, 1975. The distinction between seizure, exchange, and gifting was made by Kenneth Boulding in The Economy of Love and Fear: A Preface to Grants Economics, Wordsworth Publications, 1973.

14 K. Marx, Das Kapital, in Karl Marx and Friedrich Engels, Werke, Band 23, Berlin: Institut für Marxismus-Leninismus beim ZK der SED, 1962, pp. 102-03. Max Weber, Wirtschafts-Geschichte, München and Leipzig: Verlag von Duncker \& Humblot, 1923, pp. 174-76. Regarding the contrast between inward-facing morality and outward-facing morality, see ibid., pp. 57-59, 268-69, 303-04.

15 See the explanation according to F. Knight on pages 16 and 24 of Hideo Aoyama, The Defence of Business (in Japanese), Sobunsha, 1952.

16 F. A. Hayek, op. cit., pp. 6ff. 
ing the product $\mathrm{A}$ is providing are of course largely unknown to $\mathrm{B}$, and quite possibly even to A as well. The same is true of the product B is providing. Exchange, through the medium of money, constitutes one part of the social reproduction of the results of the social/occupational division of labour amongst a vast number of people. As Marx put it, this is a world of things in which relationships between people are manifested as relationships between things, and a society ruled by a market mechanism that transcends human intentions. The morals needed to live in this kind of civilised society (commercial society) naturally differ from those needed to live inside a community. Brotherly love and reciprocal cooperation will not do. It is necessary for one to acquire self-responsibility, sensible self-interest, and an ethos along the lines of Franklin's "thirteen virtues," which include traits such as sincerity, adherence to contracts, industry, frugality, self-control, and trustworthiness.

The progress of history has not moved in a direct line from communities to spontaneous order (markets). Society forms concrete social constructions through various relationships of control/subordination, and various communities are positioned at their base or as their constituent elements. Franklin's virtues were accepted as virtuous in 18th century America. In pre-modern societies, economic liberty was constrained by the nature of these societies' social constructions, suppressed by predominant moralities, or viewed with contempt. Buying and selling was conducted in the agora of ancient Athens, grain was imported by the state (polis), and the oikos was maintained by slave production, but in the public square citizens debated the "good life." Aristotle accepted the validity of trading in the goods needed in daily life, but denounced "the art of making money" $[\chi \rho \eta \mu \alpha \tau \iota \sigma ı \kappa \eta]$ (commerce) as unnatural. The flourishing of commerce in the Roman Empire gave rise to the Roman legal system that would later serve as the inspiration for modern private law, but this does not mean a philosophy of commerce had been created.

With the downfall of classical antiquity, the net of markets/social divisions of labour collapsed, and medieval Europe then re-emerged from rural farming villages. Under the control of a universal church, feudal latifundia and hierarchical social orders took shape. Addressing the major cities and commerce that were beginning to prosper at the time, the 13th century theologian Thomas Aquinas criticised usury (the charging of interest) and preached the conducting of buying and selling on the basis of a "fair price." Even in Confucian countries that had no religious taboo against commerce such as that found in Aquinus' Christian moralism, commerce was seen as something not to be engaged in by those in the literate class. Generally speaking, commerce was not conducted by the upper classes (landed aristocracy in Europe, scholar-officials in China, Brahmin in India, Samurai in Japan, and so on), and the morals of these classes 
differed from those of merchants. Economic liberty was not asserted as a philosophy until the modern era.

On the one hand, the expansion of trade and embryonic stirrings of capitalism sparked by the discovery of new continents were too powerful to be contained within the leather satchel of scholasticism, and changed the nature of late scholastic economic thought in the 16th and 17th centuries. On the other hand, they also gave rise to mercantilism as a philosophy of the pursuit of wealth and power unfettered by morality. The words of Thomas Mun, "the Merchant is worthily called the Steward of the Kingdoms Stock ... a work of no less reputation than Trust" ${ }^{17}$, demonstrate both the confidence of merchants and a new understanding of value concerning economies (national wealth). Montesquieu's response, "The spirit of commerce produces in men a certain feeling for exact justice, opposes on the one hand to banditry and on the other hand to those moral virtues that make it so that one does not always discuss one's own interests alone and that one can neglect them for those of others," ${ }^{18}$ demonstrates insight into the rule-forming character of the commercial world and the positioning of the morality of commerce as "mid-level" in comparison to Christian aristocratic moral standards by an enlightened aristocrat.

Next I would like to examine the creation and development of economic liberalism by focusing on the key terms "free trade" and "laissez-faire."

\section{III}

The terms "free trade" and "laissez-faire" are known as slogans or short-form expressions of economic liberalism, and their meaning is taken to be self-evident. Historically, however, they have not always had a single definition, and the process of the transformation and consolidation of their semantic content is illustrative of the formation and maturation of economic liberalism.

"Free trade" is normally understood to mean a state of trade in which the cross-border trading of goods is conducted without tariffs, with tariffs of an equivalent amount to the indirect taxes that would be levied if the products were made in the country into which they are being imported, or with a low rate of tariffs only for products not made in the country into which they are being imported. This is the meaning of the term from Adam Smith onward. ${ }^{19}$

Up until the first half of the 17th century, however, "free trade" referred to

17 Thomas Mun, England's Treasure by Forraign Trade, or, The Ballance of our Forraign Trade is the Rule of our Treasure, 1664, p. 1.

18 Montesquieu, The Spirit of the Laws, Pt. 4, Bk 20, Chap. 2, Cambridge Political Text, p. 339. 
the movement to abolish or reform the privileges of the Merchant Adventurers of England (regulated) guild or the London (old) East India Company. In 1650 a committee was formed to study "whether it is necessary or not for England to open the way to easier and freer participation than (Chartered) Company or trade guild." ${ }^{20}$ This concern about privileged trading companies was one of the attacks levelled against various monopolies. Monopolies are constructed on three types of foundations: privileges granted by the crown, suppression of domestic competition (guilds, apprentice systems, and so on), and protective trade policies. Domestic monopolies were largely broken up during the course of the Long Parliament (1640-1653). Each country on the continent had its own complex system of tariffs (in France, for example, transit duties, various feudal levies, local taxes, and prohibitions against the transport of foodstuffs between provinces remained in place until the French Revolution), but in England a unified domestic system facilitated the flow of goods throughout the country. Many trade guilds/companies were established by charter in England in the 16th and 17th centuries, including the Merchant Adventurers of England guild (woollen textile exports), the Eastland Company (Baltic Sea trade), the Levant Company, the Muscovy Company, the East India Company, and the Africa Company (providing slaves to the newly discovered continents of North and South America), but apart from the East India Company, which underwent steady modernisation and development, they became the targets of the "war against monopolies" and had for the most part lost sway by the era of Bourgeois revolutions.

Protectionism concerning trade in general, on the other hand, continued for a very long time. Particularly during the period between the Glorious Revolution and the Industrial Revolution, the joint protection system conducted under the direction of parliament was a mercantilism unique to Britain. The "joint protection system" was a system combining the protection of manufactured goods and the protection (and encouragement of export) of agricultural products (wheat). Not only the demands of early industrialism, but also the interests of agrarian capitalism ("gentleman capitalism"), through elements within the landed aristocracy who were pursuing the enclosure of arable land and the agricultural revolution, were deeply involved in this system, and the stability of the food supply created by the agricultural revolution also had the benefit of bol-

19 J. F. Rees, "Free Trade," ESS, Vol. VI, p. 440. The early definition of "free trade" given here is based on this article. As a specific usage of "free trade" I came across on my own, in the diary of Henry Heusken, who came to Japan as the secretary to Townsend Harris, he records attempting to preach the benefits of "free trade" and explain that by trading with all countries equally tariffs can be levied as desired.

20 See, Hisao Ohtsuka, Works, Vol. I (in Japanese, Iwanami Shoten, 1969. Originally, The History of the Rise of the Stock Company, 1938), pp. 185ff., pp. $441 \mathrm{ff}$. 
stering industrial capital. In addition, the colonies of the West Indies and (the Southern part of) America were considered essential as both a source of raw materials for import and a destination for the export of manufactured goods. Colonial trade was exclusive (anti-foreign) and preferential. ${ }^{21}$

The "free trade" spoken of in the numerous essays on current affairs published by "Tory free traders" such as Nicholas Barbon, Dudley North, and Josiah Child in the 1690s is not the same as Smith's liberalism. Firstly, these essays were criticisms of the Whigs' special balance of trade margin theory that advocated prohibition of trade with France, and their authors were connected to interests such as the East India Company and the Levant Company. Most of the "free traders" were opposed to prohibitions on trade, but many of them endorsed the levying of tariffs in accordance with national interest. ${ }^{22}$ Secondly, they took for granted the ownership of colonies and colonial trade mentioned above. Their stance therefore differed from Smith's liberalism.

William Petty and John Locke were writing from the middle to the end of the 17th century, while François Quesnay, David Hume, James Steuart, and Adam Smith wrote their major works in the second half of the 18th century. During this time there was a period of appeasement policies towards France, a period of renewed tensions, and the Seven Years' War by which Britain's supremacy over France was established, and a new stage began in the theory of

21 "Gentleman capitalism" is my own characterisation. "Proper mercantilism theory" forms the backbone of Kobayashi's theory of British mercantilism (an economic theory of primitive accumulation), and is also used in the studies of Friedrich List. This "proper mercantilism theory" also includes the Bank of England and the government bond system.

22 The classic text on "Tory free traders" is W. Ashley, "The Tory Origin of Free Trade," QJE, July, 1897, pp. 335-71, but there are parts of it in need of revision. According to Chuhei Sugiyama, Josiah Child's A New Discourse of Trade, 1693, was written before he become involved in the East India Company and thus should not be seen as a defence of this company. He did not belong to the Tory Party, and ideas contrary to free trade, such as demands for strict enactment of policies prohibiting the importation of manufactured goods or the importation of raw materials, were at the core of his assertions (See Sugiyama's Commentary added to his translation of Child's pamphlet, University of Tokyo Press, 1967). According to Yoshikazu Kubo, in Nicholas Barbon's A Discourse of Trade (1690) the main goal is not the trade margin itself but rather increasing employment (the number of people employed) by promoting exports (trade surplus). And while he asserted that trade in any form must not be prohibited, he endorsed high protective tariffs to protect domestic industries. The fact that North presented the most unlimited theory of free trade may have been simply because of the brevity of the text. Influential opinion in Japan sees Smith as circling above the extension of proper mercantilism. Taking a different approach, Chuhei Sugiyama traces the genealogy of theories of free trade independent of political parties or factions. Sugiyama, "The Birth of Free Trade Theory," in Sugiyama ed., Free Trade and Protectionism (in Japanese, Hosei University Press), 1985. 
free trade, including as it pertained to the problem of the American colonies.

While there is a sense in which the phrase "laissez-faire, laissez-passer" might seem to more succinctly express the concept of economic liberty than the term "free trade," like "free trade" it was first used with a slightly different meaning from how it would come to be understood later on.

According to what Turgot states in Éloge de Vincent de Gournay (1759), the first forerunner of what would become the term "laissez-faire" was uttered when a merchant said to Jean-Baptiste Colbert, "Laissez-nous faire (let us do [as we like])." ${ }^{23}$ This remark was made at a meeting of the Commerce Advisory Committee headed by Colbert (August Oncken estimates it to have been around $1680^{24}$, and is thought to have been an expression of opposition to excessive administrative management. According to testimony given by Georges Weulersse as a collaborator of Vincent de Gournay's, when Gournay was alive he had often repeated the maxim "laissez-faire, laissez-passer." "Laissez-faire" expressed a desire for liberty of production, "laissez-passer" a desire for liberty in the distribution of products, and together they are expressed in the Japanese term jiyu hōnin [non-interference liberty]. But he did not leave any written record of this coinage. ${ }^{25}$ According to Takumi Tsuda, however, Gournay did indeed record these phrases at the end of the manuscript of a talk given at the end of September, 1753, in which he writes, "these terms are a constant source of activity, and so to us they are sure to be a constant source of wealth." ${ }^{26}$ If this is the case, the theory that these terms were first used (in writing) by d'Argenson and Mirabeau the Elder must be discarded. ${ }^{27}$

Gournay (1712-1759) was a merchant who worked for many years as a distribution control officer, and he was surrounded by others with an interest in

23 T. Tsuda trans. and ed., Turgot's Economic Writings (in Japanese), Iwanami Shoten, 1962, pp. 58-59.

24 A. Oncken, Die Maxime Laissez-faire et laissez-passer, ihr Werden, 1886, S. 120.

25 G. Weulersse, “Gournay, J. C. M. Vincent de (1712-59)," ESS, Vol. VII, 1933, pp. 6-7.

26 T. Tsuda, éd. Mémoires et Lettres de Vincent de Gournay, 1993, p. 34. A translation of this text is to be included in Gournay's Economic Writings, soon to be published by Hosei University Press (not yet published). I have quoted with the author's permission a response I got to a question concerning the etymology of the terms "laissez-faire" and "laissez-passer" dated October 27th, 1996. I would like to express my gratitude to him here.

For Tsuda's views on Gournay, see his presentation "d'Argenson and Gournay: two prototypes of Free Trade Theory" at the annual meeting of JSHET in 1978 (a summary can be found on page 76-77 of Annual Report of JSHET, Vol. 17, 1979), "Conflict between Free Trade and Protectionism: On the Eden Treaty in 18th Century France" (in his ed., op. cit., esp. pp. 35-36). Tsuda's Commentary to his trans. and ed., Cantillon, Essais sur la nature du Commerce," University of Nagoya Press, 1992 (esp. pp. 251ff.) 
economic issues. This was not a sect or faction, but a circle of discourse and debate that included people with conflicting views, such as Turgot and Forbonnais and its members produced French translations of many books on economics, including Child's A New Discourse of Trade (the annotated translation of which was banned). Gournay's circle was the centre of intellectual fermentation on the topic of economics in France.

What Gournay meant by "laissez-faire" and "laissez-passer" was an endorsement of the liberty of commerce and industry within France, and indeed a doctrine of "non-interference" when it came to things like the abolition of guilds, elimination of privileges, and various regulations of commerce, but it was a stance that still demanded protection in regard to foreign countries. This can be seen as a position in line with reality from the perspective of the disparity between England and France in manufacturing productivity. Oncken characterises Gournay as "not a genuine physiocrat, but rather a liberal mercantilist." Weulersse, too, understands his stance to be one of internal liberty, external protection. ${ }^{28}$

The most widely known account of the etymology of "laissez-faire" is that given by John Maynard Keynes, citing Oncken, in his book The End of Laissez-Faire (1926), but not only does this account itself require revision from today's perspective, his ignoring of the differences in the content of laissez-faire in Gournay and the physiocrats, even though they are pointed out by Oncken, is unforgivable from the standpoint of academic history. ${ }^{29}$

So the epigram "laissez-faire" was passed from Gournay to Mirabeau the Elder who set it down in print, but in the physiocrats descended from Quesnay it came to mean not only the liberty of industry and commerce within France but also laissez-faire in a more literal sense that included overseas trade. I cannot address physiocracy in detail here. ${ }^{30}$ I will only note that while Quesnay had engaged in positive research such as 'Fermier' (1756), when the 'Tableau economique' was completed on the basis of these works the reproduction struc-

27 According to August Oncken, laissez-faire was first used in print (1736) by D'Argenson, while laissez-passer was added by Mirabeau the Elder and set down in his letter (1768). This would mean it took roughly a hundred years to go from "laissez-nous faire" to "laissez-faire, laissez-passer." a. a. O., S. 121 et al. Terence Hutchison states that Boisguilbert and D'Argenson used these terms before Gournay, but if he means in the form "laissez-faire, laissez-passer" he is mistaken. Cf. T. Hutchison, Before Adam Smith, p. 225, 401 (n. 7).

28 A. Oncken, a. a. O., S. 121; G. Weulersse, op. cit., p. 7

29 Keynes, "The End of Laissez-Faire," Essays in Persuasion, in ditto, The Collected Writings of John Maynard Keynes, ed. by Elizabeth Johnson and Donald Moggridge, vol. 9, Macmillan \& Cambridge Universtiy Press, 1972, pp. 278-79.

30 See chapter 2 of this book (Comparative Study), "Liberalism in Physiocracy." 
ture it describes was taken to be the immutable truth of socio-economic nature expressed by physiocracy (rule by nature). The 'Tableau economique' was a great achievement as the first schematic illustration of social reproduction (circulation) in the history of economics, but as an example of economic liberalism it can be described as quite peculiar or eccentric. Economic liberalism is normally based on an interpretation of the market mechanism as being composed by the acts of free individuals. Quesnay assumes a 'good price' of grain, but this price is something given from the outside, and he thinks a 'good price' will be easily maintained by the liberty of trade with other nations. The idea that the abolition of special privileges and restrictions in every part of the economy will realise a natural order is very clear and easily understood, but taken together with the dogma of the "non-productivity" (not creating net product) of commerce and industry, the problem of being out of step with reality is unavoidable. ${ }^{31}$ Unlike Smith's idea of progress toward realisation with ongoing historical detours, Quesnay's conception of natural law/natural rights lacked any temporal or procedural aspect. Le Mercier de la Rivière states, "il n'est rien de plus simple, ni de plus évident que les principes fondamentaux et invariables de l'ordre naturel et essentiel des sociétés." 32

\section{IV}

"Free trade" and "laissez-faire" are known as slogans of economic liberalism. Those who asserted these ideas in the most straightforward manner, however, were not the only representatives of economic liberalism. I believe British classical economic thought is intellectually and theoretically suited to the label of classical liberalism, and Marshall can be seen as its heir. While there is a way of using these terms in which laissez-faire and economic liberalism are equated, ${ }^{33}$ neither Ricardo nor Smith used the terms "laissez-faire” or "laissez-passer."

31 The 1786 trade agreement between Great Britain and France (the "Eden Treaty," dissolved in 1793) was free trade in character (broadly lowering tariffs), and was promoted by the physiocrat Du Pont de Nemours. Tsuda's paper (in Sugiyama ed., op. cit.), which is also cited in chapter 2 of this book (Comparative Study), "Liberalism in Physiocracy," lays out in detail the blow suffered by French industry. I have expressed some doubt about whether the wailing of the French merchants and industrialists should be considered an accurate reflection of what actually occurred. My review of Sugiyama ed., Free Trade and Protectionism, in Economic Studies, Iwanami Shoten, April 1987, p. 179.

32 Le Mercier de la Rivière, L'Ordre naturel et essentiel des sociétés politiques. Collection des économistes, 1910, p. 30. Research on the disciples of Quesnay, including Mirabeau the Elder, focusing mainly on their view of taxation can be found in Kiyoji Kizaki, The Formation of the French Political Economy (in Japanese), Miraisha, 1976. 
There are a few instances of their use in Britain before John Stuart Mill, but they only caught on as English phrases after Mill wrote in Section XI of Book V of Principles of Political Economy (first published in 1848), "Of the grounds and limits of the laisser-faire or non-interference principle." ${ }^{34}$ John Elliott Cairnes, "last of the British classical economists," wrote, "Only let us remember that it [laissez-faire] is a practical rule, and not a doctrine of science." ${ }^{35}$ Cairnes aimed to criticise Bastiat in particular, and emphasised the distinction between policy slogan and scientific understanding. Generally speaking, in contrast to the conception of laissez-faire of the 18th century physiocrats and that of Bastiat in the middle of the 19th century, in which, putting aside the academic value of the "Tableau économique," transcendental ideas such as natural rights, natural law, providence, and pre-established harmony stand out more than proof and reasoning, the British classical school is characterised by its use of laissez-faire as a principle that governs policy while at the same time recognising exceptions to this rule. In Smith there is approval of maritime shipping laws (the Navigation Acts), prohibition of the issuance of low value (under five pound) bank notes, and legally determined rates of interest. Among these, his support for maritime shipping laws was particularly unyielding as an understanding of reality based on the principle "national security is more important than wealth." Once British power reached a stage that made them no longer necessary, these laws underwent several revisions, and four years after the Navigation Acts of 1845 they were completely abolished. Smith's proposal to prohibit the issuance of low-value bank notes was a technical measure to prevent financial disruption, and he states that laws that can be seen as infringing upon "the security of the whole society" and "a violation of natural liberty" can also be necessary. ${ }^{36}$ Here he can be said to have been exercising utilitarian judgement. As for his endorsement of legally determined interest rates, this was a slip of the pen, and he accepted the objections of Jeremy Bentham. While he accepted such actions in

33 As it is used in J. Viner, “Adam Smith and Laissez Faire," Journal of Political Economy, Vol. 35 (1927), pp. 198-232; ditto, “The Intellectual History of Laissez Faire,” Journal of Law \& Economics, Vol. III (1960), pp. 45-69, for example, "laissez-faire” is equivalent to "economic liberalism in general."

34 cf. L. Robbins, The Theory of Economic Policy in English Classical Economy, 2nd ed., 1978, pp. 43-44. E. R. Krittel, “Laissez Faire” in English Classical Economics," Journal of the History of Ideas, Vol. 27 (1966), pp. 610-11.

35 J. E. Cairnes, "Political Economy and Laissez-Faire," in Essays in Political Economy: Theoretical and Applied, 1873, pp. 250-51 (Citation taken from E. R. Krittel, op. cit., p. 610 (n. 2)).

36 Smith, Wealth of Nations, Glasgow ed., 1976, Vol. I, p. 324. Specifically, he states that prohibiting the issuance of low-value bank notes and making all bank notes exchangeable are the two necessary limitations to banking. Ibid., p. 329. 
special cases, in principle Smith's stance in favour of individual liberty (against state interference) was unwavering. He asserted that stagnation and decay would occur wherever free competition was absent, even when it came to the domains of education and religion. Even regarding the third of Smith's three main expenses of the state, the expenses of public works and public institutions, Smith believed it was best for these to be left to private management to the greatest extent possible, and to see in him an early awareness of social capital (infrastructure) and the origins of the welfare state seems a bit of a stretch (that such interpretations have arisen is a result of the breadth and depth of his thought).

In examining classical liberalism with Smith as our starting point, ${ }^{37}$ I would like to begin by laying out the following as the defining characteristics of this school of thought.

\section{Philosophical background and analysis}

It is undeniable that Smith's thought was deeply rooted in natural law philosophy, but, as noted above, when it came to concrete policy judgements he was often utilitarian. His argument for giving up the American colonies, too, was based not on the natural rights of their residents but rather on the excessive financial

37 Opinions are divided on how to view the mainstream of economic liberalism. Keynes distinguishes it from a doctrine of transcendental laissez-faire harmony, seeing it instead in a group (orthodox school) of "leading economists" who were science-based and realistic, and therefore not in all respects adherents of the doctrine of harmony. Specifically, this lineage stretched from Adam Smith to Alfred Marshall (or Arthur Pigou).

Lionel Robbins saw the whole of British classical economics, from Hume to Mill and including Jeremy Bentham, as the classical form of economic liberalism. (See Robbins, ibid.)

Hayek, from his perspective of political liberalism and economic liberalism being one and the same, and with the idea of spontaneous order as his criterion, saw the liberalism of Bernard Mandeville, David Hume, Adam Smith, Alexis de Tocqueville, Lord Acton, Ludwig von Mises and himself as true liberalism (individualism), and that of others such as Mill and Bentham as false liberalism tainted by continental rationalism and utilitarianism (see Hideo Tanaka and MasaharuTanaka trans. and eds., ibid.).

Hayek's thought requires careful consideration, but his rejection of utilitarianism is difficult to understand. I draw mainly on Robbins and Keynes. Marshall differs from classical liberalism both in terms of the era in which he was active and the content of his thought, and while in some respects he was closer to new liberalism (discussed later), fundamentally I prefer to view him as a successor of Mill.

Chapter 1 of this book (Comparative Study), "Fragile Clock: Early Newtonianism and the Formation of Political Economy" is an attempt to illuminate this topic from a unique perspective. "Antecedent paradigms and Smith's Political Economy" addresses how three intellectual groups that preceded Smith were integrated as elements of his economic thought. 
burden keeping them would place on Britain. His friend David Hume was a utilitarian philosopher, and the philosophically radical faction influenced by Jeremy Bentham, among them Mill in particular, held fast to utilitarianism while incorporating distinctions in the nature of pleasure and suffering. As I have briefly mentioned, in contrast to a laissez-faire approach that appeals to natural law or divine providence, assumes an existing order, and tends to assert the principle of laissez-faire without exception, in the case of a utilitarian philosophy the merits of each case are considered from a utilitarian perspective, and such an approach thus differs from a transcendental or sweeping laissez-faire doctrine, its weapons of choice being evidence and analysis. David Ricardo, too, is said to have been influenced by Bentham via Mill, and all of the major economists up until Marshall, with the possible exception of Thomas Malthus, were utilitarian. When it comes to the discussion of what utilitarianism is, I cannot hope to resolve this question here. Topics such as the debate between "act utilitarianism" and "rule utilitarianism" are beyond the scope of this essay. What I would like to point out is the following.

Logically speaking, utilitarianism cannot be said to be intrinsically or necessarily connected to individualism (liberalism). The doctrine of the greatest happiness is one that can also go hand in hand with totalitarianism. There is also the question of whether what is to be sought is the greatest happiness of the citizens of a particular country or of humanity as a whole. In the case of classical economists, and Mill in particular, their utilitarianism was an individualist utilitarianism. Earlier I mentioned that Mill thought of individual liberty as "sacred ground," and this was the foundation of his thought concerning economic policy as well. At the same time, however, adopting utilitarianism as a standard means illuminating and determining the limits of laissez-faire on the basis of this standard, and conversely outlining the scope of state obligation/interference that is its counterpart. Mill believed that policy intervention was justified in cases in which it could be rationally predicted in advance that leaving things up to non-interference would necessarily result in a bad outcome. His approval of Edward Wakefield's doctrine of organised settlement, advocacy of state-funded immigration, ${ }^{38}$ and endorsement of using state funds to purchase gentry-owned land for the establishment of small independent farms ${ }^{39}$ all come from this perspective.

Since the state is the subject of policy, it is normal for the scope of utilitar-

38 J. S. Mill, Principles of Political Economy, Book 5, Chapter 11, Sects. 14 and 15. Shiro Sugihara, History of Economic Thought in Britain (in Japanese), Miraisha, 1973, pp. $42-54$. See, Donald Winch, Classical Political Economy and Colonies, 1965, Chapter 9, Sect. 3

39 J. S. Mill, "Land Tenure Reform," Collected Works of John Stuart Mill, Vol. V, 1967, pp. 689-767. See Shiro Sugihara, J. S. Mill and Today, Iwanami Shoten, 1980, pp. 121-27. 
ianism's greatest happiness to be its citizens. At least when it came to a subjective viewpoint, however, the policy stance taken by these utilitarians was thought to also be correct from the perspective of other Western states and not just according to their own country's interests. Ricardo's theory of international trade, for example, was a demonstration of the fact that the specialisation of comparatively superior industries was beneficial to both countries involved, and following in his footsteps Mill took up the topic of the ratio in which these benefits were allocated. Mill's qualified approval of the protection of fledgling industries has been interpreted as a utilitarian judgement concerning the optimal distribution of resources from a global (the world of Western nations) perspective and not a doctrine of protecting the industrial capital of less-developed nations. $^{40}$

Marshall, too, advocated a "system of economic liberty," but its philosophy was utilitarianism. As a result, it was not a hands-off, harmony doctrine laissez-faire approach. He was well aware of the fact that the marginal utility of money is different for the wealthy and the poor, and that the narrowing of the gap between rich and poor is desirable from the standpoint of the greatest happiness. His theory also incorporated the fact that the existence of increasing returns industries and diminishing returns industries destroys the harmony of laissez-faire, and he acknowledged both the good and bad aspects of the control of large corporations. He took a positive view of American anti-trust law, and recognised the necessity of an impartial organ overseeing the combining of businesses. ${ }^{41}$ Throughout his career he consistently supported free trade as Britain's trade policy, and suggested that if America also adopted free trade policies it would be advantageous from the perspective of its industrial circumstances. ${ }^{42}$ As a general doctrine, however, he recognised that free trade could not always be said to be advantageous from the point of view of each country's national interest and had to be assessed on a case-by-case basis. At the same time he also pointed out that free trade excelled in terms of simple clarity and preventing corrupt relationships between politics and industry, while protectionism, on the other hand, as could be seen in the case of Germany, tended to increase the price of goods and decrease real wages. ${ }^{43}$

40 J. S. Mill, Principles of Political Economy, Book 5, Chapter 10, Sect. 1. Concerning the concept of liberty in Marx, the most important socialist of Mill's era, see chapter 4 of this book (Comparative Study), "The Market Economy System and Liberty: By way of Marx's Theory."

41 Alfred Marshall, Industry and Trade, 1st ed., 1919, 4th ed., 1923, Book 3, Chapter 7, Sect. 3. Concerning the role of the state in relation to cartels, see Chapter 10, Sect. 4

42 A. Marshall, "Some Features of American Industry: Report for "Cambridge Moral Science Club” Nov. 17, 1875," Early Writings of Alfred Marshall, Vol. 2, 1975, pp. 355-77. 
As can be seen in these examples, economic liberalism based on economic analysis grounded in utilitarianism acknowledged exceptions and special cases, adopting a stance that emphasised an understanding of reality rather than perfect one-dimensional symmetry. In contrast, the so-called "popular economics" of thinkers like Frederic Bastiat was a transcendental, harmony doctrine laissez-faire approach that employed natural law and providence. The popular explanatory texts of Martineau and Marcet, which were even more unscientific than Bastiat's writings, can truly be said to be expositions of harmony doctrine laissez-faire.

\section{Enrichment and the working class}

The power of production increasing through the division of labour, expansion of markets, and the accumulation of capital, the lowest level of society being raised in spite of the existence of inequality, and overall enrichment being realised-this was Smith's vision and understanding. In order for this enrichment to proceed smoothly, Smith asserted that various institutions or policies existing at the time (or in some cases in the very recent past), such as trade associations, apprenticeship systems, privileged trading companies, import bans, high tariffs, export incentives, regulation of colonial industries, and preferential trade practices had to be abolished. This was true "reform" in the circumstances of the time, and, as I noted in Section I, economic liberalism does not say all existing systems should be left as they are in a "laissez-faire" approach; it is on the contrary a school of thought that points toward systematic reform to enable laissez-faire (the market mechanism) to function. Departing from the standard view, Lionel Robbins counts Jeremy Bentham among the members of the British classical school, and Bentham's attempt to rationally organise Britain's complicated and inconsistent traditional laws was also a reform undertaken for the sake of liberalism. A rational legal system, after all, is presumably required in order for the market mechanism to function smoothly. The movement to abolish

43 Ditto, "An Export Duty on coal, Letters to The Times, Apr. 22 and May 9, 1901," Memorials of Alfred Marshall, 1925, pp. 320-22; ditto, "Discussion on Mr. Schuster's 'Foreign Trade and the Money Market," Journal of the Institute of Bankers, Vol. 25 (Feb. 1904), pp. 94-98; ditto, "Memorandum on Fiscal Policy of International Trade," (1908), Official Papers of Alfred Marshall, 1926, pp. 365-420. Summaries of these articles along with the article cited in the previous note can be found in Masaharu Tanaka, "A list of the writings of Alfred Marshall," Konan Economic Review, March 1983, p. 48 and "A list of the writings of Alfred Marshall: Continuation," Konan Economic Review, Sept. 1983, pp. 92-93, 97-98, 102-03. As an early paper addressing the thought and movement critical of free trade with a focus on the tariff reform question of 1903, see A. W. Coats, "Challenge to Free Trade: Fair Trade and Tariff reform, 1880-1914," Chuhei Sugiyama ed., Free Trade and Protectionism, Hosei University Press, 1985. 
the Corn Laws and the revision of the poor laws were also examples of reform.

When we talk about the overall enrichment of society, the key issue is the working class that makes up the majority of the population. Smith believed that when society is in a state of progress, the natural rate of pay (wages) will rise, and this was something he welcomed. Smith distinguished profits from wages and interest, and was the first to structurally understand how economies revolve around the axis of capital's pursuit of profits (the formation of average rates of profit). ${ }^{44} \mathrm{He}$ believed that when society was in a state of progress (a state of progressing in the accumulation of capital) wages would rise, and that this would be a good thing. He endorsed capitalism (a system of natural liberty that was its distillation), but not the perspective of capitalists, whom, on the contrary, he distrusted.

The misery of factory workers caused by the industrial revolution presented a reality that undermined Smith's theory of overall enrichment. While Malthus' principle of population was not shared by all of the members of the classical school, to Mill in particular it loomed over the future of the working class as a major obstacle to their happiness. While in the second version of his Essay on the Principle of Population Malthus himself considered improving the lives of the working class through their "moral restraint," Mill and others in the philosophically progressive school were pioneering advocates of birth control (which was illegal at the time). This illustrates how passionate he was about improving the standard of living of the working class (breaking the vicious circle of poverty $\rightarrow$ moral decline $\rightarrow$ poverty). On the other hand, his expectations of labourers' cooperatives proved misplaced as a hope for system-wide change, and his paradoxical expectations of a stationary state turned out to be nothing more than a fantasy (these expectations of a stationary state were inconsistent with the core themes of his other writings).

The supposition that members of the British classical school insisted unremittingly on laissez-faire policies runs counter to the facts. Senior and others spoke of the necessity of widening streets and regulating sewers in major cities from the perspective of public health and hygiene, even though doing so would entail restricting private ownership to some extent, ${ }^{45}$ and Mill advocated management of London's water supply by the municipal authorities. From Smith to Mill they were consistent in endorsing public support for primary education. ${ }^{46}$ Regarding factory laws, Malthus, Senior, and McCulloch all approved of ban-

44 See, Noboru Kobayashi, The Formation of the System of the Wealth of Nations (in Japanese), Miraisha, 1973, Chap. 4, Sect. 1-3.

45 L. Robbins, op. cit., p. 89.

46 Ditto, op. cit., p. 102. 
ning the employment of children. Labour unions had dual aspects of liberty of association and monopolisation (opposition), and most of the members of the classical school were ambivalent toward them. From a socialist perspective, the reform policies of the classical economists regarding the working class were for the most part stopgap or hypocritical and based on class bias ("false consciousness"). I would not go so far as to say that the classical economists were always correct. I do think, however, that the realistic perspective they possessed should be further excavated and reassessed. ${ }^{47}$

So the classical economists, while they desired improvements in the lifestyle (enrichment) of the working class, could not be confident of a bright future. In Marshall's era this outlook changed. On the basis of the rate of increase of wealth surpassing the rate of increase of the population in Britain, and statistical proof of an upward trend in the real wages of the working class, ${ }^{48}$ he saw that possibilities for generational advancement through education (unskilled labourer $\rightarrow$ skilled labourer $\rightarrow$ craftsman $\rightarrow$ professional) had opened up for working class children. The nightmare of the population principle had been dispelled, at least when it came to Britain. The overall enrichment found in Smith can be said to have been once again recognised by Marshall.

\section{Free trade}

I have already discussed some aspects of the classical school's view of trade, and now I will look at it from a slightly different angle. The energy of the British free trade movement reached its peak with the abolition of the Corn Laws in 1846. Beginning with the Anglo-French trade agreement of 1860 (the Cobden-Chevalier Treaty), free trade between each of the civilised nations was realised (although in the end it would not last very long), and Britain itself upheld this tradition until the 1920s.

In the last quarter of the 18th century, Britain went from being an exporter to an importer of grain. The Corn Laws enacted in 1815 to prevent an expected

47 The socialist view of capitalism is "Notwithstanding the huge increase in wealth, the working class becomes poorer." Mill, while harbouring considerable sympathy for socialism, never accepted more than small-scale socialist experiments because he feared socialism's optimism concerning the possibility of improving human nature and abolition of competition would bring about decline.

48 The work of statistician Robert Giffen (R. Giffen, The Progress of the Working Classes in the Last Half Century, 1884; ditto, Growth of Capital, 1889-his first paper was published in 1878) showed that in Britain the rate of increase of the national wealth was greater than the rate of increase of the population, and the real wages of the working class were increasing. Regarding Marshall's views on the working class see chapter 6 of this book (Comparative Study), "Progress and Liberty in Marshallian Economics." 
influx of grain $\rightarrow$ collapse of grain prices caused by the end of the Napoleonic wars prohibited the importation of grain as long as prices were below a fixed standard but allowed importation without tariffs if prices rose above this line. These Corn Laws were of course in violation of the principle of free trade. It is well known that Malthus approved of these laws from the perspective of the protection of agriculture (including consideration of its necessity to national security), while Ricardo advocated free trade and opposed them on the grounds of preventing a decline in the accumulation of capital through low grain prices and of promoting international interdependence (a guarantee of peace) through making the international division of labour more thorough. ${ }^{49}$ Ricardo's argument was formulated in terms of a view of capital accumulation in which capital accumulation progresses $\rightarrow$ population (of the working class) increases $\rightarrow$ demand for grain increases $\rightarrow$ (law of diminishing returns) $\rightarrow$ the position of marginal land is lowered $\rightarrow$ grain prices increase $\rightarrow$ rent increases/monetary wages increase (real wages are fixed) $\rightarrow$ interest rates go down $\rightarrow$ accumulation of capital declines (extreme stationary state). This argument includes the view that wages and interest rates are in conflict with each other (and also the theory mentioned earlier that trade between countries benefits both sides through specialisation in comparatively advantaged industries).

Ricardo's argument was the guiding theory of the classical school of economics that opposed the Corn Laws, and was handed down to its other members such as Mill. It was not the classical school economists, however, but the theory and movement of the so-called "Manchester School" of Richard Cobden, John Bright, and Frederic Bastiat that demonstrated the greatest rigour in striving to completely abolish the Corn Laws. ${ }^{50}$ The Manchester School's view of free trade differed from Ricardo's theory. It held that the free importation of grain would increase the purchasing power (money) of grain exporting countries and thereby increase exports of British industrial goods (particularly cotton/cotton textiles). As a result British industry would prosper, and both interest rates and wages would increase. This was why the Corn Laws had to be abolished. This

49 Regarding the fact that given the extent of the excess export capacity of the continental nations a flood of grain imports capable of dealing a fatal blow to British agriculture was not about to occur even if free importation of grain were allowed, and that Ricardo too had been thinking about the gradual liberalisation of importation, see Masaharu Hattori, The Debates on Corn Laws (in Japanese), Showado, 1991. Regarding the anti-free trade movement centred in Birmingham in the first half of the 19th century, see Tamotsu Nishizawa, A Group of Dissenting Economists: Ideas of Economic Policy of the 19th Century Birmingham School (in Japanese), Iwanami Shoten, 1994.

50 Jiro Kumagai's Study on the Economic Thought of the Manchester School (in Japanese, Nihon Keizai Hyoronsha, 1991) is an excellent study of the Manchester School, and the following account is based on it. 
sort of assertion was directly connected to Lancashire spinning interests, and, unlike Ricardo's somewhat abstract theory, was concretely and practically easy to understand. It was therefore natural that it would be taken up by the Anti-Corn Law League. To describe Cobden as simply a popular economist, however, is not necessarily accurate. He also criticised the restriction of latifundia through entailment laws, and advocated the establishment of farmer-owned farms through the "free trade of land."

I would like to conclude by pointing out some of the limitations of classical liberalism. What I discuss here applies not only to economic liberalism but also to political liberalism. To begin with, when these liberals spoke of the liberty of individuals, the "individuals" they were referring to were male heads of households; women were treated like minors, subordinate to and under the protection of these patriarchs. Only Mill asserted that women were persons whose abilities equalled those of men, while Marshall, on the other hand, emphasised the virtuousness of housewives and opposed even granting women university degrees. The ensuing rise of the movement for the expansion of women's rights beginning at the start of the 20th century and continuing to the present day is widely known.

The second point I would like to make is that 19th century liberalism was limited to white Western societies. Not only were uncivilised native peoples ignored, but even residents of Asian countries with ancient civilisations were seen as intractably irrational and fit for education by force. As a result, there was a tendency to justify conquest, colonisation, and semi-colonial dependency as civilising education. Even Mill was guilty of this. ${ }^{51}$ It was not until after the Second World War that these biases were to some extent corrected and human rights and liberty were recognised as universally belonging to all human beings.

Third, there is the problem of "free trade imperialism," the practice of pursuing trade through military force and the semi-colonisation of Asian countries with national policies of isolationism (Japan's escaping this treatment was exceptional). This is a point on which values diverge. Both nationalism that sim-

51 His maintaining that China's banning of opium imports was unjust, for example, amounted to supporting the opium wars. John Stuart Mill, On Liberty, in ditto, Essays on Politics and Society, ed. by J. M. Bobson, Collected Works, Vol. 18 (1977) (University of Toronto Press, 1977), pp. 293-95.

Regarding Mill's views on colonial rule, see Representative Government (1861), Chapter 18. Mill's assessment that if his country stopped governing its colonies and dependencies with non-European populations they would fragment, engage in warfare, and cause the situation to spiral out of control cannot be said to have been entirely mistaken when he made it in 1860. The inadequacy of his understanding of the misery of the colonies and dependencies and the fact that he did not perceive non-Europeans' capacity for liberty, however, is undeniable. 
ply rails against imperialistic incursions and views of history that see only the globally civilising effect of capitalism are one-sided. What cannot be denied, however, is the enormous and heart-rending sacrifices that have been made in the process of this "civilising" for the sake of the interests of capital and the struggle for influence between the great powers.

\section{V}

"Comparison of liberal economic thought" can have various meanings. First, it can refer to a chronological comparison in relation to the stages of development of capitalism. Second, it can imply a typical, spatial comparison between countries or regions. There are aspects in which these two types of comparison are related. The first compares changes in liberal economic thought corresponding to the development of advanced capitalist countries, but this includes spatial shifts, such as the position of leading country in the capitalist world shifting from Britain to America, and there is also the influence of developing countries (their connection to the capitalist world). In the second type of comparison between countries or regions the particularities of their traditional social structures must be considered, and at the same time attention must be paid to the stage of development at which they made contact with the capitalist world and became capitalist (or were colonised).

Both the first and second approaches are based on the assumption that economic thought developed in relation to the realities they examined. In a broad sense, thought separated entirely from reality is indeed impossible. In a narrow sense, however, thought is not completely governed by the stages or circumstances of reality, and the working of the intellect possesses its own autonomy. As a third approach, it is therefore possible to shelve the stages of development or types of capitalism and compare the various types of economic thought found in liberalism. ${ }^{52}$ Losing sight of the gap between thought and reality, the first and second approaches will presumably fall into basic reductionism.

In this section I will give an overview of the changes and responses of economic liberalism while bearing in mind the stages of development of advanced capitalist countries, and in the next section I will present a survey of the intellectual reactions in less developed countries and regions. ${ }^{53}$

Global free trade, which reached its peak in the 1860s, was already being challenged by protectionism in the 1870 s, and toward the end of the century British industrial hegemony was undermined and overtaken by Germany and

52 Chapter 10 of this book (Comparative Study), "Liberalism and its Foundation: Mainly in the Cases of Walras and Hayek" is a typical example of this third approach. 
America. Meanwhile, within Britain itself public attention had been drawn to so-called "social problems," and the view that they could not be solved merely through liberty and self-responsibility (self-help) and required large-scale state (social) intervention was gaining strength. A. V. Dicey states that from 1865 onward public opinion and the law began to shift from individualism to collectivism. ${ }^{54}$ According to this chronology, the turning point had already come in Mill's later years, and the entire period during which Marshall was active belongs to the era of collectivism. But while in some respects Marshall adopted the ideas of this era, and there were also points on which he agreed with "new liberalism" (support for progressive taxation, for example), I included him in the previous section because I believe that classical economic liberty formed the core of his thought.

While the term "new liberalism" has several other uses, ${ }^{55}$ the "new liberalism" I am referring to here was an intellectual movement that stretched from the late 19th century to the beginning of the 20th century, accommodated the trend toward collectivism mentioned above, and attempted to reorganise liberalism. It is commonly associated with Thomas Hill Green, Leonard Trelawny Hobhouse, and John A. Hobson, ${ }^{56}$ but each of these thinkers was quite different. Here I will give a brief outline of Green and Hobson.

T. H. Green is said to have been the first to raise the banner of new liberalism. He was a philosopher and social reformer who died at the early age of forty-four in 1882, having spent his entire career at Oxford University. Heavily in-

53 The three-stage theory of economic policy in relation to the stages of development of capitalism (types of dominant capitalism) (Uno theory) not only includes the mistaken belief that capitalism ends at the imperialist stage, but to consider intellectual history as conforming to this view is excessively crude. Rostow's theory of the stages of economic maturity covers everything up to the present day but is extremely broad. When it comes to comparisons of type, on the other hand, while the viewpoint of the history of land systems and Gerschenkron's typology of fungible goods (banks, states) of spontaneous industrial capital in the transformation to capitalism of less-developed countries (limited to Europe) deserve attention for illuminating actual historical processes, there are aspects of thought (more developed countries' assimilation of information and the international flow of ideas, for example) that cannot be reduced to these perspectives.

54 A. V. Dicey, Lectures on the relation between law and public opinion in England during the nineteenth century (1st ed., 1905, 2nd ed., 1914), London: Macmillan, 1948, pp. 64ff.

The preface to the second edition contains a detailed account of the marked development of collectivism from the start of the 20th century.

55 The similar term "neoliberalism" is used to refer to Hayek, the New Austrian School, and Milton Friedman, all of whom I discuss later.

56 T. H. Green (1838-1882), L. T. Hobhouse (1864-1929), and J. A. Hobson (1858-1940). Hobhouse, who is not discussed here, was a multi-faceted writer who was first a newspaper editor and later a professor of sociology at the University of London. 
fluenced by German philosophy, he rejected utilitarianism and adopted the philosophy of idealism. Around 1870 idealism was commonly thought of as a Tory philosophy, but Green embraced it while maintaining a liberal perspective. He asserted the positive liberty of a person's "self-realisation" more strongly than negative liberty. A passionate idealist who preached the importance of public spirit and attracted many young followers, he wanted the state to accept responsibility for things like old age pensions, social security, and the strengthening of factory laws, and to guarantee every individual a "good lifestyle." ${ }^{57} \mathrm{He}$ was a liberal who adhered to idealistic individualism, but in some respects, such as maintaining an organic theory of the state and advocating the strengthening of the ancient Greek curriculum, he differed quite sharply from the traditions of liberalism. Regarding economic liberalism his stance was actually negative.

In contrast to Green, a philosopher (more specifically, a political philosopher) who died young, J. A. Hobson was non academic economist and critic born twenty years later who lived to be eighty-two (dying in 1940). He was a prolific writer, and his heyday as a new liberal lasted until around the First World War. He consistently upheld the doctrine of free trade. ${ }^{58}$ Domestically, however, he opposed "laissez-faire" and was oriented toward social reform. In his view of society he opposed atomistic individualism, stating that the universal fact of the biological world that individuals are the means of their species also applied to human beings, and placed a high value on the significance of the state. ${ }^{59}$ Unlike Green, however, he supported a utilitarian basis for policy and not organic theory totalitarianism.

Hobson saw the economic problems of the era in the inequality of distribution and low income (under-consumption) of the working class. He referred to the economics of Mill, Cairnes and Marshall as "new economics," and while he praised it for taking a more humanitarian perspective than old-school economics, he also asserted it was not sufficient to solve the economic and social problems of the era. Inequality of distribution runs counter to the liberal idea of equality of opportunity at the starting point of individual competition, and does

57 Green exerted a large influence, particularly with his posthumous Lectures on the Principles of Political Obligation, 3 vols., 1889-1890. Eijiro Kawai criticised both Marxism and fascism on the basis of Green. My discussion of Green in this text is based on C. Brinton, “Green, T. H.," Encyclopedia of Social Sciences, Vol. VII, (1932), pp. 164-65.

58 Even during the First World War he defended free trade on the following grounds. (1) Protectionism reduces the overall national income, taking away funds that should be used for things like education. (2) Protectionism raises the price of goods, burdening the impoverished working class. Free trade is the harbinger of civilisation and peace. J. A. Hobson, The New Protectionism, 1916, included in J. A. Hobson: A Reader, M. Freeden ed., pp. 168-73. Page numbers in the following notes also refer to this anthology.

59 Ditto, The Crisis of Liberalism, 1909, pp. 64-67, 76-77, 80. 
not allow fair competition to arise.$^{60}$ Furthermore, inequality of distribution also leads to accumulation of unearned income $\rightarrow$ excessive aggregation of capital $\rightarrow$ excessive production (low wages of the working class $=$ under-consumption/insufficient effective demand). Hobson in fact discussed under-consumption (the trend toward insufficient effective demand) in several texts, and developed his most detailed arguments in The Physiology of Industry, his debut work (written together with Albert F. Mummery and published in 1889) praised by Keynes. ${ }^{61}$ The theory of under-consumption presented in his wellknown book Imperialism (1st ed., 1902; 3rd ed., 1938) takes the simple form described above (see Chapter 6). He asserts that under-consumption (insufficiency of domestic effective demand) gives rise to an imperialism that demands colonial markets. According to Hobson, colonies are not actually profitable and are in fact unnecessary. All that is needed is for free markets to be maintained and inequality of distribution occurring within the country redressed. The merit of Imperialism as a text lies in its description of the actual state of imperialism through the careful use of statistics, a process touched off by the Boer Wars, but I do not have the space to present this here.

There are two ways to correct inequality of distribution. One is to raise wages. To this end the role of labour unions is deemed important. As I pointed out earlier, classical liberalism (Mill, Marshall) was ambivalent toward labour unions. The other is income redistribution through progressive income and property taxes. Hobson enthusiastically welcomed Lloyd George's "People's Budget" of 1909.62 (Marshall also endorsed the "People's Budget"). Like Green, Hobson sought the extension of educational opportunities to the lower classes and the implementation of social security. ${ }^{63}$ Hobson did not become a socialist, but he was in favour of cooperation between liberals and socialists. The assertions of the new liberals showed the path toward a far-off "welfare state." ${ }^{64}$

60 Ditto, The Social Question, 1901, pp. 33-34.

61 Keynes, Works, Vol. 7, The General Theory of Employment, Interest and Money (originally 1936), pp. 364-70.

62 J. A. Hobson, The Significance of the Budget, 1909, pp. 193-95.

63 The Old-Age Pensions Act was passed in Britain in 1908, followed by the National Insurance Act in 1911.

64 In Hobson, there is a "small country, few people" view in which primarily agricultural countries like Denmark are seen as good, while countries like Britain, in which agriculture has been ruined and the population concentrated in large cities, are viewed as aberrant. See J. A. Hobson, Imperialism: A Study, 3rd ed. (1938), New York: George Allen and Unwin, p. 93. Throughout his career Hobson resented not having been accepted at universities (see, Confessions of an Economic Heretic, 1938). It was because of his theory of under-consumption that he was rejected as a university educator. This fact evinces the degree of entrenchment of Say's law prior to Keynes. 
The next corner in the development of economic liberalism was turned by John Maynard Keynes. As was noted in the previous section, in the 1920s Keynes became aware that economic realities were undergoing a major transformation. Having deemed socialism including Marxism impoverished thought, he pinned his hopes on "wisely managed capitalism." ${ }^{65}$ This intuition acquired the theoretical equipment it required and reached fruition in The General Theory of Employment, Interest and Money (1936). Regarding currency, Keynes advocated abandoning the gold standard, or, in other words, adopting a "managed currency." Regarding trade, he supported the use of both free trade and protection depending on the circumstances. Whether Keynes' economic thought is considered liberalism depends on the perspective of the writer describing it. To Friedrich Hayek, Keynes was an enemy of liberalism. But according to Keynes' own view, since modern capitalism cannot function well without appropriate management, such management is necessary in order for liberal economies to survive. Hayek and Keynes are thus in accord when it comes to the liberal society they have as their aim, and in conflict when it comes to their understandings of the means (policies) to be employed in realising it. ${ }^{66}$ Returning to Hayek's perspective, however, Keynes' thought is not the road to liberty but rather a "means" that is itself a negation of this "aim." My own view is that while diverse interpretations of Keynes' approach are possible, broadly speaking, it belongs in the category of liberal economic thought. ${ }^{67}$

After the Second World War, the influence of Keynesians grew in each of the developed capitalist nations, beginning with America, and Keynesian economic policies (monetary/financial policies) were put into practice. Meanwhile, in many countries the social policies advocated by the "new liberals" were becoming steps toward the welfare state. ${ }^{68}$

The third era of liberal economic thought was the 1980s. While the first

65 Keynes, The End of Laissez Faire (originally published in 1926, included in Works Vol. 6. Essays on Persuasion). At this point in time Keynes was critical of other thinkers, including Marshall, for lacking a sufficient understanding of changing realities. Regarding Keynes' political philosophy, see chapter 7 of this book (Comparative Study), "The Political Philosophy of J. M. Keynes: Burke and Keynes."

66 In a letter (28 June 1944) responding to Hayek's having given him a copy of The Road to Serfdom, Keynes writes, "In my opinion it is a grand book... You will not expect me to accept quite all the economic dicta in it. But morally and philosophically I find myself in agreement with virtually the whole of it. ... I should say that what we want is not no planning," in John Maynard Keynes, “A letter to Keynes” [28 June, 1944], in ditto, Activities 1940-46, Shaping the Post-war World: Employment and Commodities (The Collected Writings of John Maynard Keynes, vol. 27), ed. by Donald Moggridge, Macmillan \& Cambridge University Press, 1980, pp. 385-87. Cf. R. F. Harrod, The Life of John Maynard Keynes (Macmillan, 1951), pp. 436-37. 
two transformations had been reflections of the movement away from classical economic liberty and toward the expansion of the authority/capacity of the state, the line of thought that had its heyday in the 1980s advocated the restoration of classical economic liberalism, or indeed going beyond it to extend economic liberty even further. This is sometimes called "neoliberalism," but to avoid confusion with the earlier "new liberalism" discussed above I will refer to it as "libertarianism." It did not, of course, appear out of nowhere. Hayek had formulated a libertarian social philosophy in the 1940 s. ${ }^{69}$ Milton Friedman had also written about social philosophy at the start of the $1960 \mathrm{~s}^{70}$ The reason it rose to prominence in the 1980s was that the policy shifts enacted by the Thatcher (British Prime Minister 1979-90) and Reagan (American President 1981-1989) administrations, at a time when inflation and "stagflation" had cast doubts upon Keynesian policy and it was being suggested that the welfare state had hit a dead end, were in some respects in line with libertarianism. Here let us examine Friedman, who was more concerned with actual policy than Hayek.

In the essay “Adam Smith's Relevance for 1976," ${ }^{71}$ printed in a collection of writings commemorating the 200th anniversary of The Wealth of Nations, Friedman wrote that Smith's observations were just as correct in 1976 as they had been two centuries earlier. Smith had written The Wealth of Nations as a radical reformer in the midst of excessive regulation, and the situation in America at the time Friedman was writing was likewise one of suffocation by

67 The following passage in the Preface to the German Translation of his General Theory illustrates the possible extreme interpretation of The General Theory as totalitarian: "the theory of output as a whole, which is what the following book purports to provide, is much more easily adapted to the conditions of a totalitarian state," in John Maynard Keynes, "Preface to the German Edition," in ditto, The General Theory of Employment, Interest, and Money (The Collected Writings of John Maynard Keynes, vol. 7), p. xxvi. American right-wing Keynesians asserted that the production of military supplies and equipment could provide effective demand. Taken as a whole, however, there can be no doubt that Keynes' thought was liberal. He did, however, indeed assert that management by a wise elite was indispensable, and if this point is emphasised too one-sidedly, Hayek's fears will be realised.

68 The new liberals' aim was the welfare state, but their thought was not innovative when it came to economic fluctuations and downturns in particular. Keynesianism, on the other hand, is more than anything a policy doctrine for dealing with severe downturns and large-scale unemployment. Keynesianism is not without affinity for the welfare state, however, and after the Second World War they can be thought of as having become fused.

69 See my Commentary to F. A. Hayek, Market, Knowledge, and Liberty, op. cit.

70 See Friedman, Capitalism and Freedom, 1962.

71 M. Friedman, “Adam Smith's Relevance for 1976," Adam Smith and the Wealth of Nations Bicentennial Essays 1776-1976, ed. with an introduction by F. R. Glahe, 1978, pp. 7-19. 
over-regulation. Smith's thought was thus well suited to the times. What were lamented as flaws in Smith's position were only his concessions to state authority, as could be seen in his acceptance of legally fixed interest rates, and the risk of permitting expansive interpretations of the third obligation of the state, public works and public institutions. ${ }^{72}$ With such assertions Friedman advocated restricting the state's field of play even further than Smith had, leaving even more up to market forces. He too acknowledged that negative effects on "third parties" caused by economic externalities (public harms) could arise outside of markets, but responded that there was no guarantee that "failures of the market" would be corrected by the government, and recklessly adding "failures of government" was not the correct response.

Free to Choose, ${ }^{73}$ which Friedman co-authored with his wife, is a straightforward, one-sided text covering a wide range of fields. The understanding of the market mechanism that underlies the entire work is borrowed from Hayek. After giving concrete examples of how effective the market mechanism is at making use of the knowledge dispersed throughout a society in order to improve it, and conversely how inefficient and squandering of creativity regulation is, the Friedmans argue that the Great Depression of the 1930s was not caused by inherent contradictions of capitalism but instead occurred simply because of mistakes made by the Federal Reserve System and the raising of interest rates when a policy of monetary easing was required. They rejected Keynes' theory of insufficient demand, and adopted an extremely optimistic view of the market mechanism. They also said that social welfare was an inefficient system that oppressed individual liberty. Regarding the education system, they asserted that the compulsory integration of black students was an infringement on liberty. Excessive pharmaceutical testing and regulation deprived consumers of their freedom. It is the market that protects consumers. It is not labour unions that protect workers, but hiring competition. In order to prevent inflation, the rate of increase of the money supply must not exceed the rate of economic growth. Even if it is assumed there are various other factors behind rises in commodity prices, both historically and theoretically monetary expansion can be seen as the biggest cause of inflation. As a result, if the average rate of economic growth is $3 \%$, the rate of expansion of the money supply should be legally fixed at $3 \%$ (monetarism). ${ }^{74}$ In practice Keynesian-style discretionary policy is influenced by special interests, and, when it comes to laxity, inevitably invites inflation. Having begun at the end of the 19th century, the trend toward the expansion of the state and the limitation of liberty had already come as far as the realisation

72 Ibid., pp. $12 \mathrm{ff}$.

73 M. \& R. Friedman, Free to Choose: A Personal Statement, 1979. 
of the 1928 platform of the Socialist Party of America. But at the same time the winds were beginning to change. This is what the Friedmans said in their book.

In the short-term, at least, Free to Choose can be said to have been in line with the mainstream. This was also the period during which the figure of Hayek loomed the largest. But what happened after that? Keynesians say the "conservative reaction” ended. But it is difficult to see Keynes' position as having been fully restored. What is important for us is to consider libertarian thought from a more long-term, fundamental perspective.

\section{VI}

Differences in economic thought have naturally arisen between developed capitalist nations and developing nations and regions. The main factors that give rise to these differences are as follows:

(1) What was the leading school of economic thought in developed capitalist nations during the critical period in which the nation or region in question encountered capitalism and whether it would embark on the road to becoming capitalist on its own (or be colonised or semi-colonised) was determined?

It is natural for this to heavily influence the modernising thought of developing regions/nations.

(2) What was the nature of the traditional thought in the nation in question? Traditional thought is of course closely connected to traditional social structure, but what is directly at issue here is the thought itself.

(3) The state of nationalism, its strength and way of operating. This is deeply connected to (1) and (2), but I would like to consider it as its own factor. Nationalism of course exists in developed nations, but in general it comes to the fore more strongly in developing nations.

(4) Along with the increasing density of the flow of information, thought becoming less regionally/nationally local and the degree of globalisation increasing. ${ }^{75}$ There were exchanges of economic thought between Britain and France in the 18th century, but up until the 1920s the barrier between speakers of different languages (English, French, German, and so on) remained quite

74 What is problematic is the question of what is to be considered "money" when it comes to things like deposit money that is not legal tender, CDs, and notes, and the difficulty of measuring the speed of the flow of money. These issues had already arisen in the debate between the currency school and the banking school in the 19th century.

75 In medieval Europe, thanks to the dominance of Latin as the language of intellectuals (and the Catholic Church), there was no intellectual language barrier. Common use of Latin lasted until the middle of the 18th century. 
high. With the establishment of the hegemony of English after the Second World War, the language barrier has been significantly lowered.

Until around 1870, France, Germany, and America, while developed nations from a global perspective, were developing nations in comparison to Britain. This group was the first-tier of developing nations. There were things they had in common as less-developed in comparison to Britain, and there were also particularities unique to each nation.

In France, as was pointed out earlier (Section III), in the middle of the 18th century there was a movement calling for liberty within the country and protection regarding other nations. The "mercantilism" that sought protection for a manufacturing sector that was immature in comparison to that of Britain continued to be advocated in works such as Chaptal's Of the Industry of France (1819). The thought of Saint-Simon can also be considered the ideology of the French industrial revolution.

The adoption of developed-nation Britain's liberalism occurred in two works published in 1803, Jean-Baptiste Say's A Treatise on Political Economy and Jean Charles Léonard de Sismondi's On the Wealth of Commerce, both of which were heirs to Smith's The Wealth of Nations. Say reorganised The Wealth of Nations into textbook-like chapters on production, distribution, and consumption, added the concept of service, introduced entrepreneurs and distinguished between capital interest and entrepreneur profit, and through "Say's law" rejected general excess supply. Say's economic liberalism reached the pinnacle of pre-established harmony "laissez-faire" in Bastiat's Economic Harmonies (1850). Sismondi, who had taken Smith as his starting point, was shocked by the panic and distress of workers in Britain in 1815, and in New Principles of Political Economy (1819) set out to make important "corrections" to Smith's system. The gist of his theory was that under-consumption $\rightarrow$ panic was built into the reproductive structure of capitalism. According to Sismondi, a society of small, independent producers was the "natural order," while a capitalism of class divisions and conflicting interests was an "artificial organisation." "Laissez-faire" was out of the question; the state must wield its power and engage in interference (social policy) to do things like guarantee some portion of land is owned by farmers. There must be a "principle of solidarity" between employers and workers. Sismondi advocated protection of craftspeople and farmers, and this reflected the distinctive structure of France in which British-style primitive accumulation was not carried out and the industrial revolution was sluggish. And while the situation of workers in France and other continental European countries was bad, it was not as bad as in Britain. The idea that policies to avoid a situation like that found in Britain were necessary was a recurring pattern in 
developing nations. Russia's Alexander Herzen, for example, looking at the proletariat and the unfolding of the 1840s revolutions in Europe, became a pioneer of Russian communitarian socialism. Sismondi was born in Geneva, but as an intellectual based in France, the most developed of the nations less developed that Britain, he was a leading proponent of this pattern. While he had started out as an economic liberal, as he matured he became an opponent of this school of thought. $^{76}$

Friedrich List was the most influential economist in Germany in the first half of the 19th century. ${ }^{77}$ Being out of office, he contributed to projects such as the formation of a customs union between the German states and the building of the railroad. He advocated protective tariffs for the sake of Germany's infant industries. In Outlines of American Political Economy (1827) and The Natural System of Political Economy (1837), he wrote that America and France must also adopt protection systems in order to become industrial nations and avoid being destroyed by superior British industry. Through these texts, along with his major work, The National System of Political Economy (1841), he became an international polemicist of the group of first-tier developing nations.

Maintaining systems to modernise the economy within the nation while attempting to improve national productive capacity by adopting protectionism towards other nations (transitional protection until it was possible to compete with Britain) was a trend that naturally appeared in the economic modernisation of developing countries. List's acuity lay in his making it clear that the free trade doctrine being advocated as universal and correct in all cases was aligned with British national interests and that in its previous stage of development Britain itself had sheltered its industry through protectionism (agricultural-industrial solidarity protectionism), and in his confirming the historical importance of mercantilism (proper mercantilism-see Section III) and its current importance to developing nations. In Farmland System, Dwarf Economy and Emigration (1842) he also attempted to reform the old southern German farmland system, create wealthy, independent farmers, and lay the foundations for a domes-

76 Sismondi, "What the Economists always repeated was laissez faire, laissez passe." The main target of his criticism was not Smith but the physiocrats and Ricardo. Regarding France, see ShizukazuYoshida, French Mercantilism (in Japanese, Miraisha, 1962), ditto, An Economic Heretic, Sisimondi (in Japanese, Shinhyoron, 1974), ditto, Study on the French Classical Political Economy (in Japanese, Yuhikaku, 1982), Keiichi Sakamoto, Formation of the Ideas of French Industrial Revolution (in Japanese, Miraisha, 1961), Shizukazu Yoshida, Recovering Saint-Simon (in Japanese, Miraisha, 1975).

77 Noboru Kobayashi studied List for many years, and the results of his research are included in his Works of the History of Economic Thought, Vols. 6, 7, 8 (in Japanese, Miraisha, 1976). 
tic market. Along with the intention of preventing proletarianisation, however, this undertaking also involved a doctrine of expansionism in the form of colonising the Balkans. Austria was dominated by cameralism in the first half of the 19 th century and need not be examined here. ${ }^{78}$

Since America was a nation without a system inherited from a previous era, unlike in Europe, economic liberalism did not have to fight for systemic change. This may actually have robbed the economics of liberalism of power until the middle of the 19th century and caused popular "laissez-faire-ism" to become dominant. The conflict between Thomas Jefferson's agrarianism and Alexander Hamilton's industrial protection at the time of America's founding is very interesting, but the economics expounded at each small university was theological laissez-faire/pre-established harmony taught by professors who were also clergymen in the Northeast (Francis Wayland, The Elements of Political Economy, 1837, etc.), and an economics of "liberalism" that defended slavery while endorsing modest social policies for workers (Thomas Cooper, Lectures on the Elements of Political Economy, 1826) taught by professors who were not clergymen in the South. In contrast to these teachings, from around 1820 to 1860 the "American System," an approach that advocated the protection of American industry, was developed by Daniel Raymond, Friedrich List (during his stay in America), and Henry Charles Carey (having been originated by Alexander Hamilton). This “American System” school opposed import economics and advocated a protectionist system that was practical from an American standpoint, but when it came to the absence or paltriness of any abstract economic theory beyond whether something was good or bad policy in the current circumstances this approach was no different from similar policy doctrines in France and Germany (with the exception of Sismondi). The development of genuine liberal economics in America would have to wait until the $1890 \mathrm{~s}^{79}$.

This concludes my overview of the commonalities and country-specific particularities of the reactions to economic liberalism in the first-tier of nations less developed than Britain in the first half of the 19th century. The second-tier

78 Austrian liberal economics begins with Carl Menger and includes von Mises, Hayek and radical liberalism (libertarianism), and chapter 5 of this book (Comparative Study), "Economic Liberalism in Austria: In the Case of Max Menger" addresses the convolutions of liberalism that reflected the actual circumstances at the time in regard to Carl Menger's older brother Max.

79 Regarding America, see Yoshikazu Kubo, Study of the History of American Economic Thought (in Japanese, Yuhikaku, 1961), ditto, History of American Economics (in Japanese, Keibunsha, 1988). Chapter 8 of this book (Comparative Study), "Pragmatism and American Liberalism: 'Intelligence' and 'Liberty'," addresses the unique intellectual fermentation in America. 
of less-developed countries, which received strong lateral pressure from the capitalist nations of Britain and the first-tier and began to transition to capitalism in the 1860s, included Russia, Italy and Japan.

In Russia, during the period of great reforms centred on the emancipation of serfs (1861-63) progressive bureaucrats proposed gradual liberal reforms and liberal landowners gathered at zemstva, self-governing bodies at the unit of the province created by the reforms, where they pursued reforms to benefit farmers (there was even a "Free Economic Society"), but crushed between the overwhelming despotic power of the state and the socialism that opposed it (the Narodniks (land communitarian socialists) who were organised around 1870 with roots in the thought of Herzen and the Marxists who appeared later) liberalism failed to thrive. In particular there was almost no room for economic liberalism. Russia's transition to capitalism was promoted by proxies of state power (foreign bonds $\rightarrow$ railway construction, development of the mining industry). Peter Berngardovich Struve began as a Marxist sympathiser and borrowed Marxist theory in his criticism of Narodnik economics, but the true character of his thought was liberal; he believed Russia was suffering from an insufficient development of capitalism, and dreamed of the "Americanisation of Russia” being made possible by adequate capitalist development. ${ }^{80}$ Sergei Witte, a leading promoter of capitalism, respected Bismarck and List and produced his own abridged translations of the latter's works. Liberal economists finally appeared in Russia as critics of socialism at the end of Russian capitalism. ${ }^{81}$

By the time the second-tier of developing nations was embarking on the transition to capitalism, protectionism and socialism had already begun to arise in the first tier nations, but this was the era in which free trade reached its zenith. As I pointed out earlier, however, in 1870 all of the major powers, with the exception of Britain, shifted toward protectionism. In contrast to the case of Russia, where, as noted above, economic liberalism was almost non-existent when the transition to capitalism began, in Japan there were economists such as Ukichi Taguchi and Yukichi Fukuzawa. ${ }^{82}$ Neither Taguchi nor Fukuzawa belonged to the government. Taguchi adhered unswervingly to liberal economic thought. He created a publishing company and launched Tokyo Economics Magazine (1879), founded an economics discussion group and later the Tokyo Economics Society, and provided venues for debate between people with various viewpoints. The translation of classic texts on economics, beginning with Eisa-

80 P. Strube, Critical Notes on the Problem of Economic Development in Russia (in Russia, 1894), p. 261. See Masaharu Tanaka, A Study of the Russian Economic Thought (in Japanese, Minerva Shobo, 1967), Chapters 6 and 8.

81 Chapter 9 of this book (Comparative Study), "The Exile Russian Liberal Economics: Soviet Socialism in Boris Brutzkus," addresses this topic. 
ku Ishikawa and Shosaku Saga's translation of The Wealth of Nations (188288 ), was also conducted by intellectuals in his circle.

While Taguchi remained an economic liberal throughout his career, Fukuzawa was more complicated. He learned economics from second-rate texts by authors such as Robert Chambers and Francis Wayland, but he seems to have discarded their theological and popular harmony-doctrine elements and extracted the essence of liberal economics. He saw free competition as good and opposed state management and governments engaging in encouragement through protection. When it came to other countries, however, he sometimes made mercantilist assertions. Even Adam Smith, it should be noted, said that national security was more important than wealth and approved of the Navigation Acts as a wise policy. In a nation attempting to grow as an independent country in the midst of the major powers, it is not strange to see state authority supervening human rights, or affirmations of "leaving Asia and entering Europe" and the bolstering of national power. Indeed, the closer we adhere to reality the more difficult it is to conceive of an ethereal economic liberalism without the slightest taint of nationalism. Moreover, as a result of the inequitable Ansei Treaties, until these treaties were reformed in 1911 Japan lacked tariff autonomy and its import duties were limited to $5 \%$. During this period the conflict between free trade and protective tariffs was therefore nothing more than a war of words. This was in stark contrast to Russia, which implemented highly protective tariffs in $1877 .^{83}$ The fact that Japan was nevertheless more successful in its transition to capitalism is presumably something that must be considered when it comes to the effectiveness of protective tariffs.

The transition to capitalism of second-tier developing countries in the 1860s, putting aside countries like Canada and small and medium-sized nations in Europe such as the Nordic countries, can be seen as the last wave of the formation of independent capitalist nations. Other regions remained colonies or semi-colonies, and for quite a long time after the Second World War I believed

82 The importation of economics into Japan began with Amane Nishi and Mamichi Tsuda, who were dispatched to the Netherlands at the end of the Tokugawa Shogunate. From 1860 to around 1881 the liberal economics of Britain, France and America were adopted. After the "political upheaval" of 1881, German historicism entered the mix and became predominant from 1887 onward. See Siro Sugihara, Western European Economics and Modern Japan (in Japanese, Miraisha, 1972) Chapter 1. Regarding Ukichi Taguchi, see a major work by Hiroshi Matsunoo, Taguchi Ukichi and the Society for Political Economy (in Japanese, Nihon Keizai Hyoronsha, 1996). Chapter 8 of Kumagai, op. cit., describes Taguchi as having shifted from Cobden-school liberalism to liberal imperialism. Regarding Yukichi Fukuzawa's mercantilist aspects, see Chuhei Sugiyama, Economic Thought in the Era of Enlightenment in the Meiji Period (in Japanese, Hosei University Press, 1986).

83 See Masahru Tanaka, op. cit., p. 83. 
they would only be liberated by the victory of socialism. ${ }^{84}$ History took a surprising turn, however, and not all but most of the countries of East Asia, followed by those of Southeast Asia and South America, set out on the path to capitalism. ${ }^{85}$ What's more, the Soviet Union fell apart, and Russia, the countries of Eastern Europe, and China are in the process of transitioning to capitalism in the name of market economies. While on close inspection the roots of protectionism remain, as a general principle I do not think it can be doubted that the globalisation of "market economies" (and "democracy") is an ongoing trend. Whether this will lead humanity to true happiness is another question, however, and it is difficult to conclude that the spontaneous order of market economies will naturally resolve our resource, environmental, and population problems.

84 My Study of the History of Russian Economic Thought, op. cit. was written from the perspective of a criticism of Stalinism, but its relativisation of Lenin was only partial, and in it I employed the methodology of the "true Marx" and Weber. I did not think that Soviet socialism was true socialism, but I believed there must be a socialism that surpassed capitalism. During the era of student protests I began to think that Locke and Smith were more fundamentally correct than Marx.

85 The "developed nations free trade, developing nations protectionism" schema applied at the stage when the most developed nation was Britain, but there are several ways in which it has not necessarily been applicable since America became the most developed country in the world following the Second World War. One is that America is a country with a tradition of protectionism and has had a tendency to push for managed trade. Another is that, while there are countries such as South Korea that have achieved economic growth on the basis of a high degree of protectionism, there are examples in which this has not been the case. Economic nationalism seems indeed to be a net minus. In Japan, too, the movement against the introduction of foreign capital/for the protection of native capital continued for quite a long time after the war. Discussion of international exploitation through the capital of developed nations flourished, but the solidifying of the foundations of the economy and employment creation effects of introducing foreign capital came to be viewed more favourably. Under the influence of Argentine economist Raul Prebisch, in the 1950s and 1960s the countries of Latin America cut off imports with high tariffs and adopted a policy of self-funded industrialisation (import substitution) focused on state-run companies, but these economies placed outside of international competition were inefficient and created hyperinflation. Escaping this situation was made possible through a comprehensive policy shift toward internationalisation, including policies such as the privatisation of state-run companies, import liberalisation, and the liberalisation of the introduction of foreign capital, and today, in 1997, Chile, Mexico, Argentina and Brazil are experiencing sustained growth of a kind they have never seen in the past. Naoki Tanaka, "Vision of Latin-America” (Asahi Shimbun, Evening 13 Feb 1997). Bernhard Fritz-Krockow, "Recovered Mexican Economy," (Asahi Shimbun, Evening 8 March 1997). 


\section{VII}

In conclusion I would like to lay out some of the somewhat problematic aspects of economic liberalism.

(1) I would like to begin by returning to liberalism and protectionism, a theme I have touched on several times and discussed at the end of the last section. I believe that while liberalism is a basic principle, protectionism itself cannot be. In this case "basic principle" means that if you depart too far from this principle fatally dire consequences are inevitable. To this I expect the following immediate objection. It is a historical fact that each nation has selectively employed liberalism and protectionism on the basis of its national interest. And the present reality is that the major nations of the world endorse liberalism (economic liberalism) as a general principle, but when it comes to specific cases they are each unwilling to relinquish their protections that violate this principle. If so, isn't protectionism the equal of liberalism? This is the objection most likely to be raised. But what would happen if, for example, each of the countries kept increasing the strength of its protectionism? The end result could only be either small-scale, uneconomic reproduction areas within blockaded national economies in which costs are higher than global market prices, or powerful countries absorbing colonies/semi-colonies and forming economic blocks (which is also uneconomical). The global market would shrink or disappear, and international political crises would increase. As consequences of protectionism, the redivision of colonies and expansion of spheres of influence combined to play no small role in causing both the First and Second World Wars.

Generally speaking, within industry as a whole the sectors whose international competitiveness is strong demand free trade, while those whose international competitiveness is weak demand protection. It may thus be argued that from the perspective of national interest liberty and protection are of equal value. But this is not the case. To begin with, the protection of specific industries leads to corrupt relationships between the people involved in the industries in question and the bureaucratic and political spheres (legislators with ties to special interests, lobbyists). This is also connected to protections and regulations having a tendency to become permanent and expand of their own accord. On top of these issues there are even more important questions, such as whether in the long-term such protections do actually coincide with national interest and whether national interest should continue to be our ultimate criterion in the first place.

In Sections III and IV, I addressed the protectionist thought found in devel- 
oping nations, and stated that there were historical reasons for its assertions. But at the end of Section VI and in footnote 85, I pointed out that protectionism cannot always be said to accurately express a developing nation's national interest. What is especially important is the practical and intellectual shifts that took place after the Second World War, and in particular following the end of the cold war. In the midst of capital's rapid progress toward informationisation and becoming globally mobile, the state of national interests has also undergone drastic change. Regarding influxes of foreign capital, it was not so long ago that cries were going up for its rejection and the protection of "native capital." Today it is not "exploitation" but the benefits of "job creation" that are being welcomed through foreign capital. "Learning" through the accumulation of international information is becoming more and more important.

The barriers between peoples are lower than they used to be and it is hoped that this trend will continue, but even today the subject of policy is still the individual nation and not the world as a whole. The degree of policy dependence on America, the only superpower, is remarkable. What is desirable is global cooperation and harmony that is neither the result of policies taken by each nation on their own nor of domination by a superpower, but this remains a distant hope.

I have stated that liberalism is a principle that points us in the right fundamental direction, but that is not to say that liberalism alone is enough. Liberalism surpasses protectionism as a principle, but today government interference/ management of the economy has become an issue in other contexts. These include the welfare state and environmental issues. Before addressing this topic I would like to say something about the ethics of economics.

(2) In Section II, I contrasted primitive/community morality and civilised/market morality on the basis of Marx, Weber, Hayek, and Polanyi. What I argue here is premised on that discussion. Economic liberty and capitalism are of course not identical. But we can only observe the concrete state of liberal economic ethics in relation to the state of economic ethics within capitalism (in cases in which capitalism is not markedly totalitarian).

Here I will discuss neither Weber's famous question of what it was that protected the unique modern capitalism that arose in Western Europe during its infancy (the 16th and 17th centuries) and fostered its particular ethos, nor the answer he proposes. What I would like to address is the question of economic ethics since the establishment of capitalism.

There is an understanding of capitalism in which it is dominated by selfishness and greed, money is omnipotent, and its "ethics" is the strong devouring the weak. This can be seen in critiques of capitalism from the perspective of Christianity, in thinkers such as R. H. Tawney ${ }^{86}$ and A. D. Lindsay, ${ }^{87}$ and in Alas- 
dair MacIntyre's After Virtue (1981), in which the author adopts the standard of Aristotelean "virtue." This is also the view of irreligious socialists. It is an understanding in which there are both points that are difficult to agree with and points that must be acknowledged.

It is a mistake to see capitalism (modern capitalism) as simply an economic society of greed and self-interest. While fraud and deception may not completely disappear in capitalism, in this highest state of development of the market economy, as it is based not on one-off, coincidental gains but ongoing business (repetition of transactions) and thus makes acquiring trust essential, the main earners become individuals and organisations that seek not illegal gains but a sustainable "appropriate level” of profits. Classical capitalist enterprises do not seek risky, massive one-time payoffs. What is needed is not an unrestrained lust for profit but rather rational restraint in the amount of profit sought. Smith says (lower level) "prudence" is needed, and according to Marshall, "It is deliberateness, and not selfishness, that is the characteristic of the modern age." 88

When we think about economic ethics in capitalism we must also consider the stage of development of capitalism and the differences between nations. Capitalism is described as a society in which money is all-powerful, and this is notably the case from the period of primitive accumulation through the period of industrial revolutions. This was the result of the marked division between a small number of wealthy people and a large majority of poor people (including both those who inherited poverty from the previous generation and those who were impoverished by the rapid development of the monetary economy) during this era. ${ }^{89}$

In countries like America in which there was no aristocratic tradition (standard of value), up until a certain point the development of capitalism

86 See the view of capitalism in Tawney's Religion and the Rise of Capitalism (1st 1926, reprint 1938) and the critique of capitalist industrial organisation from the perspective of guild socialism in his The Acquisitive Society, 1920.

87 A. D. Lindsay's The Essentials of Democracy (1929) is a remarkable book. According to Lionel Robbins, however, the understanding of classical economics seen in his Carl Marx's Capital (1973) goes no further than the assertion that it is a mouthpiece for the interests of capital. Cf. L. Robbins, op. cit., pp. 69-73.

88 Alfred Marshall, Principles, op. cit., p. 6. In contrast to modern capitalism, "No traders are more unscrupulous in taking advantage of the necessities of the unfortunate than are the corn-dealers and money-lenders of the East." Principles, p. 7.

But we cannot think of modern capitalism as wholly rational. We cannot dismiss Marshall's affirmation or silence concerning the Opium Wars or other transgressions against non-European countries and regions. Marshall's thought includes a racist belief in Anglo-Saxon superiority. 
brought with it the predominance of the naked worship of money. According to Galbraith, the so-called "Gilded Age" gave rise to the domineering practices and immoral profiteering of people like railway tycoon Cornelius Vanderbilt and the opulent mansions and society of Newport (particularly in the 1890s). But a shift in "mores" then occurred, Galbraith asserts, and by the 1930s being wealthy alone was not enough to bring you respect, with Senators and "harmless intellectuals" having come to occupy a higher position in society..$^{90}$ The development of capitalism actually lowering the social esteem of wealthy individuals is indeed an interesting phenomenon. It is perhaps connected to the expansion of the middle class and transition to a mass society.

So what then, in a positive sense, is capitalist (liberal) ethics? I have already discussed the ethics of the market economy in Section II. Since capitalism is the highest state of the market economy in which the market subsumes within itself both land and labour, the ethics of the market economy is fundamentally the ethics of capitalism. ${ }^{91}$ But capitalism is a different system from that of a simple market society. Individuals in market relationships are equal, and their relationships are not of a command/obey nature. In capitalism, individuals (including families) are in market relationships in their daily lives as consumers. When it comes to production (labour), too, labour contracts themselves have the character of a market relationship. But labour/employment is conducted through command/obey relationships within organisations in which a hierarchical order has been established. The commander standing at the summit of these command/obey relationships is the worker him or herself in the case of self-employment, while in a corporate enterprise this top position is occupied by the CEO and top executives (such as the board of directors), with the stockholders (stockholders' meetings) acting as a constraint. Unlike artisans or merchant families whose homes and workplaces are identical, in developed capitalism (and socialism) a person's business (place of work) and home (place of con-

89 Not only the surveys of the living conditions of poor people and lower class workers presented in texts such as Iwagoro Matsubara, Tokyo in the Darkest (in Japanese, 1893), and Gennosuke Yokoyama, The Lower Society In Japan (in Japanese, 1898) but even in Shimei Futabatei's Ukigumo (Floating Cloud, in Japanese, 1887) and the later works of Soseki Natsume dealing with people in the higher classes, money problems are a major difficulty faced by the characters that appear in these works. I think there are very few contemporary novels in which financial difficulties are given such weight.

90 J. K. Galbraith, The Age of Uncertainty, Houghton Mifflin (1977) pp. 61-75. Distinct from the extravagance of the upper class depicted by Galbraith, however, the staid middle class can be seen as having continued to be the central pillar of American capitalism.

91 Regarding terms such as "market economy" and "capitalism," see the last chapter of this book (Comparative Study), "Market Economy Terminology.” 
sumption/leisure) are separate.

In many cases, workplaces such as businesses, government offices, and schools engender a pseudo-communal sense of emotional solidarity that makes these organisations run more smoothly, and it is not uncommon for this to even provide meaning in the lives of the individuals who belong to them. But of course these organisations cannot ever be real communities, and there is also a lot of isolation within them. The family, on the other hand, can in a classical sense be described as the only community in a capitalist society, and within it production and resources are to a certain extent shared. Household finances overlapping the family are treated as a unit of consumption. But the extent to which family sharing and communal affection is preserved or lost differs greatly from family to family. It cannot be denied that the market economy, and capitalism in particular, has a tendency to weaken the sense of community among relatives and strengthen the independence of individuals even within their immediate families. I do not think, however, that it can lead to a complete breakdown of the family. The family is the place of human reproduction, and as such it is normal for it to retain the nature of a community.

Outside of the family, too, if I may embellish a bit on Smith's account, interactions and a sense of belonging to voluntary groups, such as a circle of friends within which there are warm "sympathies," a romantic couple, and various clubs or associations, differ from both pure market relationships and command/obey relationships. And one of the characteristics of a liberal society that deserves special mention is that it permits and actively creates diversity. As a result the potential for diversification of the reciprocal relationships between people (ethics) increases. (There are more opportunities to develop relationships with people you don't know. These are not binding, communal connections but relationships that are chosen freely).

There is a well-known pessimistic proposition that as the shift toward capitalism or the broad "rationalisation" of society progresses, the social division of labour and specialisation puts individuals in "iron cages" as professionals (experts), and hope for the full flowering of their humanity is lost. ${ }^{92}$ But as a result of the increase in leisure (disposable time) created by decreasing working hours, the progress of informationisation, and the increase in educational opportunities, in reality (from Weber's era onward, and particularly today) the possibility of achievement across multiple domains and the opportunities for average, ordinary people to engage in diverse activities and hobbies appears to have increased.

The view that liberalism and capitalism promote only atomistic individualisation can also be thought of as one-sided. ${ }^{93}$

(3) In my discussion above, I have based the economic ethics of liberal- 
ism on capitalism and depicted them as positively as possible, but can liberalism really be the only fundamental principle of society? Liberalism (economic liberalism) is definitely an important principle without which the development and diversity of each individual will be lost. But is liberalism alone enough? Libertarianism is a monist doctrine of spontaneous order. ${ }^{94}$ I cannot be completely brought around to it. As a practical matter, the question becomes whether to approve or disapprove of the "welfare state," and I would like to take a step back and consider this here.

The market system is one in which winning and losing is determined not only by skill or character but also by luck, and in various senses does not guarantee "distributive justice." Moreover, systems of private property and inheritance require not only unfairness in the results of competition but also stark unfairness in the starting conditions before competition begins. As a result, insisting that being socially vulnerable is the fault of the person in question and adhering to the single principle of self-help inevitably runs counter to our sense of justice. Demanding perfect equality (whether in starting conditions or outcomes) is impossible because it gives rise to totalitarianism, but once a society has reached a certain level of affluence and has the energy to spare, it is natural for schools of thought and movements seeking aid and social security for the

92 Weber states, "No one knows who will live in this cage in the future, or whether at the end of this tremendous development entirely new prophets will arise, or there will be a great rebirth of old ideas, or, if neither ... it might well be truly said: 'Specialists without spirit, sensualists without heart; this nullity imagines that it has attained a level of civilization never before achieved." (Max Weber, The Protestant Ethic and the Spirit of Capitalism, trans. by T. Parsons (London \& Sydney: Unwin, 1985), p. 182 (Max Weber, Die Protestantische Ethik und der Geist des Kapitalismus, in Gesammelte Aufsätze zur Religionssoziologie (Tübingen: Verlag von J. C. B. Mohr, 1947), p. 204). Weber's universal rationalisation is one that includes the paradox of rationalisation toward a certain kind of irrationality, and is by no means flat or straightforward. But this Nietzschean "the last man" proposition is difficult for me to accept. At its root Weber's thought differs from the liberalism that belongs to the philosophy of the enlightenment.

93 Regarding the view that capitalism (economic liberalism) promotes antisocial atomic individualisation, I do not think this is necessarily always the case. In the Afterword to Yasunobu Fujiwara's Reconsideration of Liberalism (in Japanese, Iwanami Shoten, 1993), he writes about his shock at his students losing their sense of solidarity and becoming private individuals, and I myself am reminded of similar experiences, but on the other hand the mass phenomenon of young people volunteering to help at the site of a disaster has emerged, something that did not occur in the past. And volunteering itself is something that is only made possible by a lifestyle that allows for it, and is therefore predicated on a "wealthy society."

94 For an interpretation in which even Hayek accepts piecemeal reform and a system that is not necessarily monistic, see chapter 10 of this book (Comparative Study), "Liberalism and its Foundation: Mainly in the Case of Walras and Hayek." 
socially vulnerable to appear. The new liberalism and reformist socialism discussed in Section V were examples of this kind of thought and activism. At the root of the awareness of social responsibility for the socially vulnerable is the idea that all human beings possess human rights. As we saw in Section I, liberty is a fundamental desire and right of human beings. But it cannot be said to be the only fundamental human right.

The idea that all human beings possess human rights appeared in the 17th century.$^{95}$ Religious conceptions of equality before God and universal salvation had been present from the distant past, but philosophies of equal human rights in our lives here on Earth appeared in the 17th century and were bolstered in the 18th century. As was pointed out by utilitarians in their critiques of this idea, things like natural rights cannot be empirically proven. (As we saw in Section IV, laissez-faire on the basis of the doctrine of harmony was expounded under the pretext of "natural rights.") But the idea of human rights itself gradually took hold in people's minds, and these rights were expanded in scope and socialised. ${ }^{96}$ As was noted earlier, this kind of change was based on an increase in society's production capacity. "New liberalism" and the reformists advocating, and to some extent realising, various forms of social security and income redistribution policies for the socially vulnerable (workers and the poor) occurred against this kind of backdrop. This can also be said to have been the first step on the path toward the welfare state.

But the character of the "welfare state" that emerged in many countries after the Second World War was very different from that of the social security policies and other measures targeting the socially vulnerable that had been pursued in the past. Attention was of course paid to socially vulnerable people such

95 Freedom of conscience and religious belief were put forward as birthrights in "An Agreement of the People" (1647) proposed by the Levellers at the Putney debates, but in the revised edition published two years later Catholics were excluded from national affairs. Cf. The Good Old Cause, C. Hill and E. Bell eds., 1949, pp. 349-52. According to G. Jellinek, Roger William, a supporter of independent religion from Salem Massachusetts, advocated the separation of church and state in 1631, stated that non-Christians should enjoy the same civil and political rights as Christians in the State, and was himself persecuted. Jellinek, Die Erklärung der Menschen- und Bürgerrechte: Ein Beitrag zur modernen Verfassungsgeschichte, 1st ed., 1895, 4th ed., 1927 (Japanese trans., 1995, pp. 89-91). There have been a lot of arguments against Jellinek's view (See ibid.). Hobbes' and Locke's theories of human rights are well known.

96 This expansion involved two processes: an extension of equal human rights, at least in theory, to women, the working class, and all races, and an internal expansion of the content of these rights. What is particularly important in relation to this text is not the Hobbesian right to survive (the right only to live), but the elevation of a right to live in accordance with societal standards of living and culture. 
as the elderly and the impoverished, but every citizen being compelled to join social insurance systems established by the state and the combined burden of taxes and social insurance premiums surpassing 35\% of income limited quite drastically the economic liberty of individuals. Today we have in fact become quite accustomed to the welfare state, and it makes us feel safe. As a result, however, the concepts of self-help and self-responsibility have been diminished, and there has been a trend toward blaming society or the government when things are not going well and the loss of the strict discipline of liberalism. Once you start looking for the ills of the welfare state the list becomes endless ${ }^{97}$ : the enormous waste caused by factors such as excessive medical treatment, the over-prescription of medication, and a lack of awareness of the cost of medical care, particularly among elderly patients; the intergenerational exploitation caused by the shifting of burdens onto the next generation in the pension system (compulsory filial piety); the expansion of the bureaucratic class to administer welfare and related costs; the improper use of funds meant for the construction of welfare facilities. I think some of these are a result of the principle or theory of the welfare state itself, and some have been caused by the technical ineptness with which particular implementations of it have been constructed.

The reason I do not want to reject the "welfare state" in spite of these drawbacks is that I share the modern fundamental human rights philosophy that everyone has the right to live a life with the highest standard of culture possible. To believe that "all men are brothers" and "human solidarity" can be realised in daily life is to lose sight of humanity's selfish nature (the correct understanding of which is a valuable inheritance of classical liberalism) and fall into the trap of totalitarianism. Through the construction of the welfare state, Lionel Robbins said, "It may very well be that some liberties have been curtailed which we should wish to retain and that some habits have been fostered which we should wish to discourage. But I cannot believe, even on a very long-run assessment of values, that, in what is perhaps a blundering way, we have not achieved considerable positive good," 98 and I am sympathetic to this way of thinking.

97 Even if the way civil servants interact with private citizens has been improved in comparison with the past, there are still many instances in which the procedures and structures of approval remain bureaucratic. In this text, I have looked at British intellectual history, but the "welfare state" in fact began with Bismarck's "carrot and stick" policy (Anti-Socialist Laws of 1878, Sickness Insurance Law of 1883) and calls for a "Wohlfahrtsstaat" ("welfare state"). This was comprehensively "governmental." But to what extent it remains bureaucratic and to what extent it can be liberalised or privatised presumably depends on the degree of maturity of the society in question. The figure of $35 \%$ mentioned here (more accurately 35.7\%) was the rate in Japan in 1992. The rate in Sweden for the same year reached 69.8\%. See the table on p. 449 in Japan Census Cruise (in Japanese, Kokudosha, 1997). 
There are more than a few ways in which the "welfare state" must be corrected through the ethics of liberalism. Self-help and self-responsibility must be strengthened. More importantly, if the "welfare" being provided grows too large it can force the principle of competition into retreat, reducing economic efficiency and causing the funds needed to provide welfare to dry up. It is well known that in socialist countries the actual amount of pensions provided becomes very small, and not enough to guarantee a living. You cannot have welfare without efficiency. For the sake of protecting and increasing the substance of fundamental human rights, too, the principles of liberalism cannot be disregarded. ${ }^{99}$

(Robert Chapeskie: Freelance Translator) (Hideo Tanaka: Faculty of Economics, Aichi Gakuin University)

98 L. Robbins, “Hayek on Liberty,” Economica, Vol. XXIII, No. 109, Feb 1961, p. 79.

In my commentary on Hayek's Market, Knowledge, and Liberty, op. cit. I quoted this passage from Robbins as a criticism that should be considered in relation to Hayek, but more than one reader thought I meant that even in Robbins there is a lack of understanding of Hayek. It is true that in this commentary, as Hayek's editor and translator, I was writing from as close to his perspective as I could, and my own views have indeed changed between that commentary and this text; I now have more sympathy for Robbins' perspective (not the Robbins of An Essay on the Nature and Significance of Economic Science (1932), but Robbins as a scholar of the British classical school) than Hayek's, and have learned a great deal from his point of view.

99 I had planned to address the question of liberalism and environmental issues, but I have already exceeded the allotted space and so will have to forego this discussion here. 